\title{
The management of chronic viral hepatitis: A Canadian consensus conference 2004
}

\author{
Morris Sherman MB BCH PhD FRCPC ${ }^{1}$, Vincent Bain MD FRCPC ${ }^{2}$, Jean-Pierre Villeneuve MD FRCPC ${ }^{3}$, \\ Robert P Myers MD FRCPC ${ }^{4}$, Curtis Cooper MD FRCPC ${ }^{5}$, Steven Martin MD FRCPC ${ }^{3}$, Catherine Lowe MD FRCPC ${ }^{6}$
}

\begin{abstract}
M Sherman, V Bain, J-P Villeneuve, et al. The management of chronic viral hepatitis: A Canadian consensus conference 2004. Can J Gastroenterol 2004;18(12):715-728.

Several government and nongovernment organizations held a consensus conference on the management of acute and chronic viral hepatitis to update previous management recommendations. The conference became necessary because of the introduction of new forms of therapy for both hepatitis B and hepatitis C. The conference issued recommendations on the investigation and management of chronic hepatitis B, including the use of lamivudine, adefovir and interferon. The treatment of hepatitis B in several special situations was also discussed. There were also recommendations on the investigation and treatment of chronic hepatitis $\mathrm{C}$ and hepatitis C-HIV coinfection. In addition, the document makes some recommendations about the provision of services by provincial governments to facilitate the delivery of care to patients with hepatitis virus infection. The present document is meant to be used by practitioners and other health care providers, including public health staff and others not directly involved in patient care.
\end{abstract}

Key Words: Adefovir; Chronic viral hepatitis; Interferon; Lamivudine
La prise en charge de l'hépatite virale chronique : La conférence consensuelle canadienne de 2004

Plusieurs organismes gouvernementaux et non gouvernementaux ont tenu une conférence consensuelle sur la prise en charge de l'hépatite virale aiguë et chronique pour mettre à jour les recommandations de prise en charge antérieures. La conférence s'imposait en raison de l'adoption de nouvelles formes de traitement de l'hépatite B et de l'hépatite C. La conférence a permis de diffuser des recommandations sur l'investigation et la prise en charge de l'hépatite B chronique, y compris le recours à la lamivudine, à l'adéfovir et à l'interféron. Le traitement de l'hépatite B dans plusieurs situations spéciales a également été abordé. Des recommandations ont aussi été émises sur l'investigation et le traitement de l'hépatite C chronique et de la co-infection par l'hépatite C et le VIH. De plus, le document contient des recommandations sur la prestation de services par les gouvernements provinciaux, afin de faciliter la prestation des soins aux patients atteints d'une infection au virus hépatique. Ce document est conçu pour être utilisé par les praticiens et les autres dispensateurs de soins, y compris le personnel de la santé publique et d'autres intervenants ne participant pas directement aux soins des patients.

\section{PREAMBLE}

Presently in Canada, an estimated 250,000 individuals are infected with the hepatitis $\mathrm{C}$ virus (HCV) and probably a similar number are infected with hepatitis B (HBV). The HCVinfected population is heterogeneous and includes those infected through the blood supply, contaminated injection drug use equipment and the use of unsterile medical equipment in foreign countries. A significant proportion of the current infections are in vulnerable populations, including persons with low incomes and unstable housing. In the future, it is anticipated that $60 \%$ to $70 \%$ of new cases will be related to substance use, with $10 \%$ to $20 \%$ of these cases being coinfected with HIV and other infections. In contrast, HBV in Canada is largely a disease of immigrant populations, with up to $70 \%$ of infected individuals born in foreign countries.

There is a new appreciation of the complexities involved in managing viral hepatitis in some patient subgroups, including vulnerable populations such as Aboriginal people, street youth and incarcerated populations, and in immigrants. It is recognised that the disproportionate number of new infections anticipated in these populations in the future requires special attention to ensure adequate care. This is particularly true for patients whose health care falls under federal jurisdiction, such as Aboriginal people and inmates in the federal correctional system.

In addition to meeting the need for updated treatment information for health care professionals, this consensus conference also provided an opportunity to identify gaps in the overall management of viral hepatitis in Canada and set the stage for future strategic direction. The effective management of individuals undergoing screening, counselling or treatment for hepatitis requires the development of a broad partnership approach. Medical treatment is an important component of the management of viral hepatitis, but it represents only one

\footnotetext{
${ }^{1}$ University of Toronto, Toronto, Ontario; ${ }^{2}$ University of Alberta, Calgary, Alberta; ${ }^{3}$ University of Montreal, Montreal, Quebec; ${ }^{4}$ University of Calgary, Calgary, Alberta; ${ }^{5}$ University of Ottawa, Ottawa, Ontario; ${ }^{6}$ Queen's University, Kingston, Ontario

Correspondence: Dr Morris Sherman, Toronto General Hospital, 200 Elizabeth Street, Toronto, Ontario M5G 2C4. Telephone 416-340-4756, fax 416-591-2107, e-mail morris.sherman@uhn.on.ca

Received and accepted for publication September 9, 2004
} 
element of what needs to be a comprehensive approach. To maximize the chances of successful therapy and minimize the long-term consequences of the disease, the root determinants of health need to be considered. The management of the patient with viral hepatitis includes, in addition to drug therapy measures, help in dealing with alcohol and other addictions, dietary management and weight reduction, and in some cases, the provision of adequate housing and nutrition. These factors provide the patient with a variety of possible treatment settings and support issues. The model of service delivery is important for some populations and can impact on health status and outcomes.

Treatment, especially for HCV, is 'labour intensive'. This limits the number of patients an individual physician can take care of. The provision of specialized nursing care would allow a larger number of patients to be treated. For this to occur, effective physician and nursing educational programs need to be developed to provide primary care providers with a basic knowledge and understanding of the wide spectrum of management issues.

In addition to addressing patient care issues, the conference also identified the importance of monitoring outcomes of prevention and care programs. There is a need for a national database to track prevention/care and hepatitis-targeted research including social and behavioural factors that influence risky behaviour. This could be used to inform the development of comprehensive counselling guidelines and innovative models of service delivery. Analysis of the data could be used to define program and support needs for hepatitis virus-infected individuals, guide best prevention and comprehensive care practices and determine the cost-effectiveness of treatment.

There is also a need for targeted social and behavioural research to determine the most effective strategies to prevent risk behaviour. Primary and secondary prevention best practices and models of care for chronic disease 'self' management are required. In developing these models, the diverse and vulnerable populations affected by hepatitis need to be engaged to articulate their health care needs across the continuum of prevention, care and treatment.

\section{INTRODUCTION}

The management of infection from hepatitis viruses has undergone rapid change in the recent past. Several new drugs have become available. New assays have been introduced for the measurement of viral load, and new information has emerged regarding the natural history of the diseases caused by these viruses, and the response to treatment.

Since the introduction of interferon-alpha for the therapy of chronic viral hepatitis, the Canadian Association for Study of the Liver has sponsored a series of conferences, at which local experts reviewed the available literature on the subject, and issued clinical practice guidelines on the management of chronic viral hepatitis. These have been published in The Canadian Journal of Gastroenterology $(1,2)$ and The Canadian Journal of Infectious Diseases (3), as well as on various Web sites. The current conference was jointly planned by the Canadian Association for Study of the Liver, the Canadian Infectious Disease Society, Correctional Service Canada, the Canadian Association of Hepatology Nurses, the Canadian Viral Hepatitis Network, the Community Acquired Infections Division, and Blood Safety Surveillance and Health Care Acquired Infections Division of Health Canada. Funding was provided by Health Canada and Correctional Service Canada. The conference was held from November 7 to 9, 2003 in Ottawa, Ontario. Invited presenters reviewed the literature, and presented expert opinions where literature was not available. A writing committee prepared a first draft of the recommendations and presented this draft to the audience, which included experts in the field, primary care physicians, HCV community and advocacy groups, provincial and territorial ministries of health and professional associations. Pharmaceutical medical directors and representatives were invited as observers. The writing committee accepted feedback from participants, and then revised the draft to produce the final document. The document will provide levels of evidence for the statements and recommendations made according to the Infectious Diseases Society of America's quality standards (Table 1) (4). These levels of evidence are given in italics at the end of the sentence.

The treatment of viral hepatitis is rapidly changing, and these changes need to be quickly incorporated into practice. Therefore, a significant number of studies have been referred to that have so far only been published in abstract form. The data have been presented at international meetings in all cases, and the conclusions from these abstracts are generally accepted as valid.

This consensus conference was not intended to provide an exhaustive overview of all of the complex issues involved in the management of viral hepatitis. The major intent was to address some of the changes in the medical management and treatment of chronic HBV and HCV where the changes since the last consensus conference have been most significant. In addition to meeting the need for updated treatment information for health care professionals, this consensus conference also provided an opportunity to identify gaps in the overall management of viral hepatitis in Canada and set the stage for future national strategic direction (see preamble).

Following publication of the last consensus conference proceedings, the guidelines were adopted by some provincial and territorial reimbursement plans to define categories of patients who were eligible for reimbursement for treatment costs. However, the guidelines were also used to define categories of patients and forms of therapy that would be excluded from reimbursement. The result was that it became very difficult to obtain reimbursement for antiviral therapy if the patient did not meet the guideline criteria, and to obtain concomitant reimbursement for growth factor therapy, even in cases when this therapy was appropriate. This issue is particularly significant in Canada given that the high cost of hepatitis treatment is borne predominantly by governments, and a relatively small proportion is covered by private insurance.

The current document is meant as a guide to therapy and does not claim to define the only way in which patients can be treated. The suitability of treatment for each patient cannot be described by this or any document. The needs of each patient should be assessed individually, and treatment costs should be reimbursed where treatment is appropriate. In addition, appropriate off-label uses of medication to support patients with chronic viral hepatitis should be available. Governments should establish mechanisms to allow reimbursement of such off-label uses where appropriate, but should also establish mechanisms to ensure that patients are appropriately treated when using compounds for which evidence of benefit has not been established by high levels of evidence (Level C; III). One 
such mechanism may be to establish committees of experts who could review individual requests for reimbursement that fall outside of the guidelines.

Managing patients with chronic viral hepatitis is time- and labour-intensive and cannot be adequately provided by physicians working alone. The best outcomes are obtained when patients are managed by a team, consisting at a minimum of physicians and nurses. Therefore, it is strongly recommended that there be support for training and deployment of nurses trained in the management of hepatitis, just as there are nurses trained to manage diabetes and cancer, and to provide palliative care. Financial support for the development of hepatitis clinics is also strongly recommended.

The present document deliberately does not specify particular groups of patients who should be treated or excluded from treatment. The weighing of the benefits of therapy versus the likelihood of response and of significant side effects is left to the individual physician. Thus, this document, unlike previous documents, does not exclude active injection drug users from therapy. In all cases, the decision to treat has to be individualized.

\section{Prevention of $\mathrm{HBV}$ infection}

\section{HBV}

Universal vaccination against $\mathrm{HBV}$ is effective in preventing the transmission of disease (Level I) $(5,6)$. In Canada, where chronic HBV infection is largely a disease of immigrants (7), some provinces offer neonatal vaccination, while others offer preadolescent vaccination. Because chronic $\mathrm{HBV}$ is the largest reservoir for the transmission of disease, neonatal vaccination may be preferable in provinces with a high proportion of immigrants from areas of the world highly endemic for HBV. In these populations, horizontal transmission in childhood is more likely (Level II) $(8,9)$.

In neonates, the use of the HBV vaccine and HBV immune globulin is highly effective in preventing HBV transmission (Level I) $(10,11)$. Furthermore, once infected, the risk of a neonate developing chronic infection is greater than $90 \%$ (Level II) (12,13). Therefore, screening of pregnant women in the third trimester of pregnancy for hepatitis B surface antigen (HBsAg) is mandatory (Level A; I). There are also Canadian economic data indicating that this is a highly cost-effective strategy (14).

\section{Assessment}

\section{TREATMENT OF CHRONIC HBV}

Baseline assessment should include HBV serology (HBsAg/anti-HBs, hepatitis B e antigen [HBeAg]/anti-HBe), and tests of disease activity (aspartate aminotransferase [AST], alanine aminotransferase [ALT]) and disease severity (clinical evaluation, albumin, prothrombin, bilirubin and complete blood count). Viral replication (quantitative HBV-DNA measurement) should be measured in patients with evidence of active disease (elevated ALT) (Level A; II). Liver histology, although not mandatory, is highly recommended in patients with active disease (Level A; II). Patients with mild disease may not require treatment despite active viral replication.

All HBV carriers should be offered testing for anti-HIV antibodies (Level A; I). Although the prevalence of HIV is low in some populations (eg, South East Asians), the impact of monotherapy with lamivudine, adefovir or tenofovir in a patient with undiagnosed HIV infection is great due to the potential for the HIV to develop drug resistance. Anti-HCV
TABLE 1

Grading system for ranking recommendations and clinical guidelines

\begin{tabular}{|c|c|}
\hline $\begin{array}{l}\text { Strength of } \\
\text { recommendation }\end{array}$ & Definition \\
\hline $\mathrm{A}$ & $\begin{array}{l}\text { Good evidence to support a recommendation for } \\
\text { use/action. }\end{array}$ \\
\hline B & $\begin{array}{l}\text { Moderate evidence to support a recommendation for } \\
\text { use/action. }\end{array}$ \\
\hline C & $\begin{array}{l}\text { Poor evidence to support a recommendation for } \\
\text { use/action. }\end{array}$ \\
\hline$D$ & $\begin{array}{l}\text { Moderate evidence to support a recommendation } \\
\text { against use/action. }\end{array}$ \\
\hline$E$ & $\begin{array}{l}\text { Good evidence to support a recommendation against } \\
\text { use/action. }\end{array}$ \\
\hline
\end{tabular}

Quality of

evidence Definition

I Evidence from one or more properly randomized controlled trial.

II

Evidence from one or more well-designed clinical trials, without randomization, or from cohort or casecontrolled analytic series (preferably from $>1$ centre), or from multiple time series, or from dramatic results from uncontrolled experiments.

III

Evidence from opinions of respected authorities, based on clinical experience, descriptive studies or reports from expert committees.

Data from reference 4

antibodies should also be measured because HBV-HCV coinfection may impact on the selection of treatment (Level A; I) (15).

Hepatitis A (HAV) vaccination is recommended in patients with chronic HBV (Level B; II) $(16,17)$.

$\mathrm{HBV}$ and hepatocellular carcinoma

Because of the increased risk of developing hepatocellular carcinoma (HCC), it is recommended that patients with chronic HBV undergo regular surveillance to detect early HCC (Level C; III) $(18,19)$. However, the risk is not equal in all infected individuals. Patients with established cirrhosis are at highest risk, but patients with noncirrhotic liver disease may also be at risk. Patients who have been documented as having inactive disease for many years and who are not cirrhotic (usually anti-HBe-positive and usually white) are at much lower risk (Level A; II) $(20,21)$. Such patients may not require surveillance.

Although there is no evidence that surveillance for HCC reduces disease-specific or all-cause mortality, surveillance with abdominal ultrasound and serum alphafetoprotein every six months is common practice. However, what little evidence exists suggests that annual surveillance is just as effective $(22,23)$.

\section{Who should be treated?}

Acute $\mathrm{HBV}$ infection does not require antiviral therapy (Level B; III).

HBV-infected individuals, whether $\mathrm{HBeAg}$-positive or HBe-negative with elevated AST and/or ALT, and HBVDNA levels greater than 100,000 copies/mL are candidates for therapy (Level A; I). When the HBV-DNA is less than 100,000 copies/mL, the likelihood of HBV-induced injury is thought to be low (24). The distinction between 
$\mathrm{HBe} \mathrm{Ag}$-positive and $\mathrm{HBe} A g$-negative patients may impact on the choice and duration of therapy. The decision to treat or not may also be influenced by the severity of disease on liver biopsy.

Observation without treatment is appropriate in patients with mild disease. However, such patients should be followed at close intervals.

\section{How should response to treatment be assessed?}

Response to treatment can be defined virologically or biochemically. A complete virological response is defined as the sustained loss of HBsAg after treatment, but this occurs only rarely (Level I) (25). In HBeAg-positive carriers, a partial virological response is defined as the sustained loss of $\mathrm{HBeAg}$ with gain of anti-HBe after treatment ( $\mathrm{HBeAg}$ seroconversion) (26). An alternate endpoint for a partial virological response is a decrease in serum HBV-DNA to less than 100,000 copies/mL (27). A biochemical response is defined as a normalization of serum AST and ALT. Liver biopsy is not mandatory to assess treatment efficacy (Level B; II) (27). Response is initially assessed while on therapy (on-treatment response). For patients treated with time-limited regimens (eg, interferon), response is also assessed after completion of therapy. The optimal time post therapy for assessing this response has not been defined.

The utility of determining HBV genotype needs to be explored, as it may impact on treatment efficacy.

\section{What treatment should be used?}

Lamivudine and interferon are both acceptable as initial treatment (Level A; I).

Interferon in $\mathrm{HBeAg}$-positive patients: Treatment should consist of 10 million international units (MIU) interferonalpha subcutaneously three times per week (TIW) or $5 \mathrm{MIU}$ subcutaneously daily for 16 weeks (Level I) (27-32). Some believe that longer duration therapy (up to 24 weeks) may be justified in selected cases (33), such as those with high viral loads (greater than $10^{8}$ copies $/ \mathrm{mL}$ ). A partial virological response (HBeAg seroconversion) may be expected in $25 \%$ to $40 \%$ of patients six months after the completion of therapy. Response rates are decreased in the presence of high viral loads (greater than $10^{8}$ copies $/ \mathrm{mL}$ ), mild hepatic inflammation (AST or ALT less than $1.5 \times$ the upper limit of normal [ULN]), age over 40 years, presence of cirrhosis and male sex.

The durability of HBeAg seroconversion after interferon treatment in white populations is high $(68 \%$ three years after stopping therapy) (Level II) (34). However, in other populations (eg, South East Asian), the durability of seroconversion may be lower (Level III) $(35,36)$.

In white populations, interferon therapy has been shown to enhance overall survival and complication-free survival in $\mathrm{HBe} A g$-positive patients who maintain post-treatment seroconversion (Level II) (37). The effect of interferon therapy on survival in Asian populations may not be as pronounced $(36,38)$.

Interferon may be more appropriate than lamivudine as initial treatment in young patients, particularly in the absence of cirrhosis, but there is no consensus on this issue. One rationale is that it may be preferable to use a time-limited form of therapy in a young patient who may otherwise have to be on therapy for many years, and who can tolerate the side effects of interferon.
Interferon in $\mathrm{HBeAg-negative} \mathrm{patients:} \mathrm{The} \mathrm{recommended}$ dosage of interferon is 5 MIU TIW subcutaneously to 10 MIU TIW subcutaneously for one to two years. The response rate is lower than for HBeAg-positive patients, and the durability of response is also less well established (Level II) (39-41).

Lamivudine in $\mathrm{HBeAg}$-positive patients: The recommended dosage is $100 \mathrm{mg}$ subcutaneously daily for up to five years or more, until a partial virological response (HBeAg seroconversion) occurs, or until lamivudine resistance develops (Level I) (42-44). A partial virological response (HBeAg seroconversion) can be expected in $18 \%$ to $25 \%$ of patients within the first year of therapy, rising to approximately $60 \%$ after three years of therapy.

The durability of $\mathrm{HBeAg}$ seroconversion after lamivudine is not as good as after interferon therapy. Continuing treatment for six months after seroconversion may improve the durability of seroconversion (Level II) (45).

There are several areas of uncertainty concerning lamivudine resistance. Phenotypic resistance is defined as the reappearance of HBV-DNA following initial disappearance using a nonpolymerase chain reaction (non-PCR)-based assay, or by a rise in HBV-DNA concentration to greater than 100,000 copies/mL in a PCR assay. Genotypic resistance refers to the demonstration of mutations in the YMDD motif of the HBV polymerase gene. Patients with phenotypic resistance have a $97 \%$ probability of having genotypic resistance (46) and, therefore, the utility of confirming phenotypic resistance by genotyping is unclear. Once resistance occurs (approximately $60 \%$ after four years of therapy) (47), it is unclear whether lamivudine should be withdrawn. Disease severity does appear to progress once resistance develops $(47,48)$, but it is uncertain whether the rate of progression is slower than in the absence of lamivudine. HBeAg seroconversion has also been reported after the development of lamivudine resistance (47). There is also a concern that lamivudine withdrawal may precipitate a flare of hepatitis, which could be fatal in patients who have underlying cirrhosis. However, the evidence supporting this is only anecdotal. No recommendation can be made regarding whether lamivudine should be withdrawn once resistance develops. Once lamivudine resistance has developed, patients can be offered treatment with interferon (if they have not previously failed interferon) or adefovir dipivoxil (see below).

Lamivudine in $\mathrm{HBeAg}$-negative patients: In $\mathrm{HBeAg-negative}$ patients, lamivudine is used at the same dosage (100 $\mathrm{mg}$ by mouth daily) (Level I) (49-51). The optimal duration of treatment is uncertain. For patients with a biochemical and virological response (eg, normal AST, ALT, and HBV-DNA less than 100,000 copies $/ \mathrm{mL}$ ) on therapy, there are no guidelines as to when treatment should be stopped. In patients in whom treatment is stopped after one year, the relapse rate is high, and possibly no more than approximately $13 \%$ of patients remain in remission. Possible end points for stopping treatment might be negative HBV-DNA by PCR or negative hepatitis B core antigen on liver biopsy. Similarly, it is unclear whether treatment should be stopped or continued once lamivudine resistance develops. However, as in patients with HBeAg-positive chronic HBV, the options to use interferon or adefovir remain.

\section{Adefovir dipivoxil}

Adefovir dipivoxil is a new nucleotide analogue that is effective in both treatment-naïve and lamivudine-resistant HBV 
infection (Level I) $(52,53)$ that will soon be available in Canada. Although initially studied as first-line therapy for chronic HBV, its role as first-line treatment in patients remains unclear. It seems to be less effective than lamivudine in inducing $\mathrm{HBeAg}$ seroconversion, and may also be less potent in inducing viral suppression. Its use as a first-line drug may also be limited because of cost considerations. It is indicated for therapy of lamivudine-resistant infection and in patients who have failed to respond to lamivudine initially and who do not tolerate or have failed interferon (54). Because adefovir is a new therapy, there are still several areas of uncertainty. Renal toxicity can occur in some cases and dose adjustments are required for patients with established renal disease. The rate of development of resistance to adefovir appears to be much lower than with lamivudine (55), but experience is limited. The durability of seroconversion in $\mathrm{HBeAg}$-positive patients remains unknown. As with all forms of HBV therapy, flares of hepatitis can occur after cessation of therapy. Combination therapy with adefovir and lamivudine to limit the development of resistance (by analogy with HIV-positive patients) needs to be explored.

\section{Pegylated interferon}

The efficacy of pegylated interferon (peginterferon) in the treatment of HBV infection is being investigated, but the available data are too limited to allow specific recommendations to be made. Preliminary data suggest that the efficacy of peginterferon is at least comparable with that of standard interferon (56).

\section{Special indications}

HBV in children: The principal goals of therapy of HBV in children are to reduce horizontal and vertical transmission of infection and minimize long-term disease-associated morbidity. The decision to treat a child must take into account that there is a significant rate of spontaneous seroconversion in childhood, which differs in different populations. In Mediterranean and Alaskan populations, $8 \%$ to $16 \%$ of children per year will undergo $\mathrm{HBeAg}$ seroconversion $(57,58)$. In Asian children with normal ALT, the rate may be $2 \%$ to $5 \%$ per year and $11 \%$ per year in those with elevated ALT $(59,60)$. Thus, by 20 years of age, as many as $80 \%$ of children will undergo spontaneous $\mathrm{HBe} A \mathrm{~g}$ seroconversion in regions of low or moderate endemicity and $25 \%$ to $70 \%$ in regions of high endemicity $(58,60,61)$. Predictors of spontaneous seroconversion include ALT greater than $3 \times$ ULN, high histological activity index, female sex and low HBV-DNA (ie, the same predictors of treatment response). Clinical trials of treatment with interferon or lamivudine provided insufficient follow-up of control groups. Other studies have shown that, by three years of follow-up, treated and control patients have the same rates of seroconversion $(60,61)$, suggesting that treatment mainly accelerates seroconversion by approximately three years. The long-term benefits of a three-year seroconversion advantage afforded by treatment have not been established. Cirrhosis and HCC are rare in children (usually less than 5\%); and do not always present in adolescents after a long period of inflammatory activity. Cirrhosis is well described in young children with short duration disease. Similarly, children who get HCC usually achieve $\mathrm{HBeAg}$ seroconversion in the first few years of life.

Interferon-alpha $6 \mathrm{MIU} / \mathrm{m}^{2}$ subcutaneously (maximum 10 MIU) TIW for 24 weeks has been approved for children with $\mathrm{HBeAg}$-positive HBV. This will achieve a partial virological response in approximately $35 \%$ of children (Level I) (62). Lamivudine, $3 \mathrm{mg} / \mathrm{kg} /$ day (maximum $100 \mathrm{mg}$ ) for one year, has also been approved, with partial virological (HBeAg seroconversion) response rates of $23 \%$ but with the development of lamivudine resistance in 19\% (Level I) (63). Therefore, treatment may be appropriate in HBeAg-positive adolescents who have failed to undergo spontaneous $\mathrm{HBeAg}$ seroconversion despite ALT greater than $2 \times$ ULN for six to 12 months. In younger patients, moderate or severe inflammation on liver biopsy may also justify treatment (Level III). Lamivudine may be more appropriate for younger patients due to its ease of administration and better side effects profile. Interferon may be more suitable in some older children in whom short-term therapy and monitoring may be required. Regardless of type of therapy, all children should continue to be followed at one to two year intervals to monitor for durability of response (Level III). Children should also be entered into long-term monitoring programs, to detect complications such as HCC (Level III).

Pregnant women: Some recommend the use of lamivudine in pregnant women with high HBV-DNA levels to reduce the risk of neonatal transmission (Level III) (64). To date, there are no reports of fetal injuries due to lamivudine. A single study (64) has shown that if the HBV-DNA levels are very high (greater than $10^{9}$ copies $/ \mathrm{mL}$ ), the rate of maternal-fetal transmission is approximately $30 \%$ despite neonatal vaccination.

Decompensated cirrhosis: Interferon is contraindicated in these patients. Lamivudine is the first choice in patients with active viral replication (HBV-DNA greater than 100,000 copies/mL) (Level I) $(65,66)$. Lamivudine may reduce or delay the need for liver transplantation in these patients. In contrast, the benefit of lamivudine in patients with advanced cirrhosis and inactive or low level viral replication (less than 100,000 copies $/ \mathrm{mL}$ ) is doubtful, and lamivudine should not be used under these circumstances (Level B; III).

HBV-HCV coinfection: Some favour the use of interferon, because it may be effective in both infections (Level III). The most appropriate method of combining interferon and ribavirin has not been established. However, no firm recommendations can be made regarding the use of interferon versus lamivudine.

Renal transplant candidates: Lamivudine treatment is recommended in all HBsAg-positive patients before and following kidney transplantation to avoid HBV reactivation following immunosuppression after transplantation (Level II) (67). Whether lamivudine should be used in patients with markers of past HBV infection (anti-HBs-positive and/or anti-hepatitis B core antigen-positive) to prevent reactivation is not clear, although HBsAg should be monitored to detect reactivation. Similar considerations apply in other circumstances where immunosuppressive therapy is used for immunologically mediated diseases.

Chemotherapy and bone marrow transplant: All patients undergoing chemotherapy or bone marrow transplant (BMT) should be screened for HBV markers before treatment (Level B; II). In those who are positive for HBsAg, preemptive lamivudine treatment should be used to prevent flares of HBV that can occur with these treatments (Level II) (68). Because flares of hepatitis occur mostly as a result of immune recovery, treatment with lamivudine can be started a few days before starting immunosuppressive therapy. There is no information to guide how long patients should be treated. For 
patients in whom immunosuppression continues (eg, after BMT), lamivudine therapy should also continue. However, once all courses of chemotherapy have been completed, lamivudine can be withdrawn (Level C). Some suggest a period of maintenance therapy of a few months after chemotherapy before withdrawal (Level C). Whether subjects with markers of past HBV infection should also be treated is unclear. Chronic HBV infection in the BMT recipient can be cured by adoptive transfer of immunity from a bone marrow donor with evidence of past HBV infection (Level II) (69). In BMT recipients who are HBsAg-positive, the bone marrow donor should be screened for markers of HBV infection to determine whether adoptive transfer of immunity would be a possibility (Level II). HIV and HBV infection: Lamivudine should never be used as monotherapy for HBV infection in untreated HIV patients because the rapid development of HIV resistance to lamivudine may jeopardize future treatment in these cases (Level II). Adefovir and tenofovir, another nucleotide analogue developed to treat HIV that is effective against both wild-type and lamivudine-resistant HBV strains, should also not be used as monotherapy for HBV-HIV coinfected patients (Level II).

The prevalence of HBV-HIV coinfection is approximately $5 \%$ but variable depending on location (70). HBV is more active and liver fibrosis is often more advanced in HBV-HIV coinfection compared with HBV infection alone $(71,72)$. Anti-HBs and HBsAg screening should be performed in all HIV seropositive individuals (Level A; II). Vaccination is recommended for those negative for HBsAg and anti-HBs. Because the HIV population in general is hyporesponsive to HBV vaccination, either a schedule using a double dose (73), or six standard doses (74), is advised (Level A; II). HAV virus vaccination is also recommended (Level B; II) $(75,76)$. A multidisciplinary approach for the delivery of care is ideal for the management of HIV-HBV coinfection, including specialists in infectious diseases and hepatology or gastroenterology (Level C; III).

In the case of HIV-HBV coinfection, highly active antiretroviral therapy (HAART) regimens containing the nucleoside reverse transcriptase inhibitors (NRTI) lamivudine and/or tenofovir are ideal given that these drugs possess virological activity against both HIV and HBV and infrequently cause hepatotoxicity (Level B; II) (77).

Adefovir should not be used because the dose used to treat HBV (10 mg/day) is inadequate to control HIV, and the doses appropriate for HIV are associated with significant toxicity. Furthermore, there is cross-resistance between adefovir and tenofovir. Tenofovir is preferred to adefovir in the HBV-HIV coinfected patient. The rates of aminotransferase normalization, reduction in HBV-DNA to undetectable levels, loss of $\mathrm{HBeAg}$ and development of anti-HBe are comparable among interferon, lamivudine and tenofovir (78-80). An advantage of tenofovir over lamivudine may be the slower evolution of drug resistance and the efficacy of tenofovir in individuals with lamivudine-resistant HBV $(80,81)$.

There are patients who require therapy for their HBV, but who would not otherwise qualify for HAART. Because nucleoside analogue monotherapy is not acceptable, these patients may need to go onto HAART, simply to allow control of their HBV (Level C; III). Alternatively, interferon could be used.

There are additional treatment issues around HBV that were not addressed in this conference. These include the management of hepatitis $\mathrm{D}$, the prevention and treatment of HBV infection in liver transplantation recipients and the treatment of $\mathrm{HBV}$ in hemodialysis patients.

\section{$\mathrm{HCV}$}

\section{Initial assessment}

Initial evaluation of suspected HCV infection involves serological testing for antibodies against HCV (third generation enzyme-linked immunoassay). Testing for HCV should be undertaken in all patients with abnormal aminotransferase levels and in those with risk factors for HCV infection (Level A; II). Risk factors include prior injection drug use, even if remote and only occasional, transfusion of blood products before 1990, and being an immigrant from countries with high prevalence rates of $\mathrm{HCV}$. In many countries from which Canada draws immigrants, large numbers of patients were infected with HCV 30 to 50 years ago, related to medical procedures using improperly sterilized syringes and needles (Table 2) $(82,83)$.

The initial evaluation should also include a careful review of the patient's history to exclude contraindications to therapy and identify areas that need attention during treatment. Particular attention should be paid to a previous or current history of psychiatric disorders, seizure disorders, cardiac and renal disease, autoimmune disease, alcohol and drug addiction, retinopathy and the presence of coinfections such as HBV and HIV. Contraindications to antiviral treatment for $\mathrm{HCV}$ are listed in Table 3 (Level B; II).

In anti-HCV-positive patients, infection should be confirmed with a highly sensitive qualitative HCV-RNA assay (Level A; II). It is impossible to treat HCV properly without viral load and genotype testing. Therefore, viral load and genotype testing has to be available in a timely fashion (Level A; I). These assays are essential to the proper management of patients and are cost efficient, in that they allow early termination of costly therapies where appropriate.

Laboratory assessment before treatment should include genotype, HCV-RNA levels where appropriate (see later), complete blood count, prothrombin time, international normalized ratio, albumin, AST, ALT, bilirubin, alkaline phosphatase, HBsAg, HIV, thyroid stimulating hormone, antinuclear antibodies, glucose, creatinine, serum or urine beta-human chorionic gonadotropin (to exclude pregnancy) and urinalysis (Level B; II). Additional tests include abdominal ultrasound and electrocardiogram (if over 50 years of age or history of cardiac disease) (Level B; II). Liver biopsy remains the most sensitive measure of disease severity and is recommended but is not mandatory before the initiation of therapy (Level B; II). Patients with genotype 2 and 3 infection, who have a high likelihood of cure, may not need a liver biopsy before treatment (Level B; I).

Sexually active females must have a pregnancy test before initiation of therapy because of the teratogenicity of ribavirin (Level B). Because urinary pregnancy testing has limited sensitivity and can result in false negative readings, serological testing is preferred. Sexually active patients, male or female, must agree to use a highly effective method of contraception during therapy and for six months following completion of therapy for the same reasons.

\section{Choosing patients for antiviral therapy}

With recent improvements in sustained virological response (SVR) using combination treatment with peginterferon and 
TABLE 2

Estimated numbers of immigrants to Canada with chronic hepatitis C (1960 to 2001)

\begin{tabular}{lclc}
\hline $\begin{array}{l}\text { Country } \\
\text { of birth }\end{array}$ & $\begin{array}{l}\text { Number } \\
\text { infected }\end{array}$ & $\begin{array}{l}\text { Country } \\
\text { of birth }\end{array}$ & $\begin{array}{l}\text { Number } \\
\text { infected }\end{array}$ \\
\hline China & 9985 & Pakistan & 1904 \\
Vietnam & 9053 & Germany & 1741 \\
Philippines & 8376 & Italy & 1577 \\
Egypt & 6476 & Fiji & 1340 \\
India & 5664 & Sri Lanka & 1310 \\
South Korea & 4232 & United Kingdom & 1212 \\
Taiwan & 4026 & Guyana & 1253 \\
United States & 3331 & Hong Kong & 1178 \\
Trinidad & 3192 & Tanzania & 1159 \\
Romania & 2707 & Greece & 1137 \\
Poland & 2526 & Russia & 1083 \\
& & Iran & 1080 \\
& & Haiti & 1053 \\
Total & & Lebanon & 1008 \\
\hline
\end{tabular}

Data from R Remis, personal communication

ribavirin, all patients, no matter what the apparent state of their liver disease, should undergo evaluation to determine whether therapy is appropriate (Level A; I). This recommendation is different than previous recommendations. The decision to treat or not to treat is complex and must consider factors such as the risk for liver disease progression, likelihood of treatment response, risk of adverse effects, patient symptoms and, of course, the patient's wishes. Although some have advocated the selective treatment of only those patients with advanced fibrosis or severe inflammation on liver biopsy, the large registration trials that have been published included a significant proportion of patients with mild inflammation and/or fibrosis. Patients with mild disease, especially minimal fibrosis, have the best response to therapy. Therefore, the exclusion of this group from treatment would lead to overall SVR rates that are inferior to usually quoted values. Second, simply because a patient has not been infected long enough to develop significant liver injury is not a reason to withhold treatment. However, for patients with mild hepatitis, the possibility of declining treatment with the hope of future advances in antiviral therapy should be discussed.

The primary endpoint of therapy is an SVR, defined as a negative serum HCV-RNA by a qualitative test sensitive to $50 \mathrm{IU} / \mathrm{mL}$ or less six months after the completion of therapy $(84,85)$. Studies have indicated that patients who achieve this outcome no longer have detectable HCV-RNA in the liver, and do not relapse in the ensuing years (86). For practical purposes, a SVR is equivalent to a cure, with fewer than $2 \%$ suffering a late relapse (Level I) (86).

\section{Drug treatment}

The best results have been obtained using a combination of peginterferon and ribavirin (Level A; I) $(87,88)$. Viral genotype has the most profound influence on the likelihood of treatment response. Manns et al (87) have reported an SVR of $42 \%$ in genotype 1 patients using peginterferon-alpha- $2 \mathrm{~b}$ at a dose of $1.5 \mu \mathrm{g} / \mathrm{kg}$ subcutaneously weekly, together with ribavirin $800 \mathrm{mg}$ daily for 48 weeks. This was superior to combination
TABLE 3

Contraindications to antiviral treatment for hepatitis $C$

\begin{tabular}{|c|c|c|}
\hline Alpha interferon & Ribavirin & $\begin{array}{l}\text { Both interferon } \\
\text { and ribavirin }\end{array}$ \\
\hline $\begin{array}{l}\text { Severe or uncontrolled } \\
\text { psychiatric disease } \\
\text { Hepatic decompensation } \\
\text { Solid organ } \\
\text { transplantation } \\
\text { (except liver) } \\
\text { Certain autoimmune } \\
\text { diseases, especially } \\
\text { autoimmune hepatitis } \\
\text { Poorly controlled } \\
\text { epilepsy } \\
\text { Neutrophils }<0.75 \times 10^{9} / \mathrm{L} \\
\text { Platelet count }<40 \times 10^{9} / \mathrm{L} \\
\text { Active serious infection }\end{array}$ & $\begin{array}{l}\text { Pregnancy or inadequate } \\
\text { contraception (males } \\
\text { and females) } \\
\text { Severe heart disease } \\
\text { Advanced renal failure } \\
\text { Hemoglobinopathy } \\
\text { Severe anemia }\end{array}$ & $\begin{array}{l}\text { Documented poor } \\
\text { compliance } \\
\text { Ongoing and untreated } \\
\text { alcohol or drug } \\
\text { abuse } \\
\text { Any other uncontrolled } \\
\text { serious medical } \\
\text { illness }\end{array}$ \\
\hline
\end{tabular}

treatment using standard interferon and ribavirin (SVR 33\% in genotype 1). In retrospect, the ribavirin dose used in this study was likely too low. Subsequent studies have suggested that $1000 \mathrm{mg}$ to $1200 \mathrm{mg}$ by mouth is a more suitable dose for genotype 1, depending on whether the patient is less than or heavier than $75 \mathrm{~kg}$ (Level I) (89). Fried et al (88) have reported a similar SVR of 44\% in genotype 1 patients using peginterferonalpha-2a at a dose of $180 \mu \mathrm{g}$ subcutaneously per week plus ribavirin, $1000 \mathrm{mg}$ to $1200 \mathrm{mg}$ by mouth daily. The initial registration studies for peginterferon/ribavirin did not distinguish between genotype 1 and genotypes 4, 5 or 6 . Therefore, current practice is to treat genotypes 4,5 and 6 as genotype 1 until more data are available (Level B; II).

Genotype 2 and 3 infection is optimally treated with a 24-week regime using peginterferon-alpha-2a, $180 \mu \mathrm{g}$ subcutaneously weekly or peginterferon alpha-2b, $1.5 \mu \mathrm{g} / \mathrm{kg}$ subcutaneously (Level I). A fixed dose of $800 \mathrm{mg}$ ribavirin by mouth daily is sufficient when using either peginterferon-alpha-2a or $-2 \mathrm{~b}$ (Level A) $(85,87)$. SVRs of $78 \%$ to $82 \%$ may be achieved.

The other major factor influencing the SVR is viral load, with better results being observed in patients with lower viral loads (eg, less than approximately 800,000 IU/mL) (87-89).

There are currently two preparations of peginterferon. At the time of writing, only one is available in Canada. The second preparation is expected in 2004. Both manufacturers have chosen to bundle the interferon and ribavirin, so that a fixed ribavirin dose is provided with each dose of interferon. This so-called bundling only occurs in Canada. In the United States and in Europe, the two drugs, peginterferon and ribavirin, are available separately. While there are advantages to bundling, the major drawback is a loss of flexibility to increase the ribavirin dose as required. The consensus conference speakers and attendees strongly recommend to the manufacturers that the two products be available in an unbundled form.

There are no direct comparisons of the efficacy of peginterferonalpha-2a and peginterferon-alpha-2b. Given the uncertainties of comparing outcomes from separate trials, no conclusions can be reached regarding the superiority of one agent over the other. The large trials differed with respect to the proportion of patients with genotype 1 , mean body weight and proportion with advanced fibrosis (METAVIR stage F3 or F4) 
$(87,88,90)$. Furthermore, although the adverse effect profiles seem comparable, different adverse event definitions were used, so that direct comparisons of the side effect profiles are not possible.

\section{Early virological response}

For patients infected with genotype 1, the likelihood that an individual patient will have an SVR can be reliably predicted after 12 weeks of therapy by assessing the early virological response (EVR) (Level I). EVR was defined in the registration studies as either undetectable HCV-RNA or at least a 2 log drop in HCV-RNA concentration. Patients failing to achieve an EVR have only a $0 \%$ to $3 \%$ chance of achieving an SVR. Therapy should therefore be stopped for these patients (Level A; I) $(88,91)$. Those achieving an EVR have a $65 \%$ to $72 \%$ chance of achieving an SVR. Quantitative HCV-RNA assays have an inherent variability that might be as high as 0.5 logs. Therefore, the EVR rule cannot be applied too strictly. Therapy should be stopped for patients who fail to achieve EVR. However, EVR should be defined as failure to achieve a decline in HCV-RNA of $1.8 \log$ compared with baseline at 12 weeks of therapy (Level B; III). Patients who achieve a $1.8 \log$ drop or 2 log drop, but who do not clear HCV-RNA from serum at week 12 should be tested with a qualitative HCV-RNA at 24 weeks (Level C; III). Those who fail to clear the virus at 24 weeks should have therapy withdrawn, because they are extremely unlikely to achieve SVR (Level A; I) $(89,91)$. Although these predictive rules were devised for genotype 1 patients, there are preliminary data that suggest that the EVR rule is useful in genotype 4 patients as well (92).

Patients infected with genotype 2 and 3 achieve EVR in $97 \%$ of cases. There is therefore no merit to measuring HCVRNA at 12 weeks in this group.

All patients who complete a course of therapy should have HCV-RNA measured at the end of therapy to define the nature of their treatment response (Level C; III). Some patients will achieve EVR, but develop breakthrough viremia before the end of therapy. It may be important, when considering future therapy, whether a patient was a nonresponder to interferon and relapsed during or after treatment.

\section{Evaluation and monitoring during treatment}

Treatment of HCV has numerous side effects that can be severe, life threatening and irreversible. Therefore, patients must be evaluated carefully and monitored vigilantly during and after treatment.

Laboratory assessments include complete blood count at weeks 1, 2, 4, 6 and 8, and then monthly. ALT, bilirubin, glucose and urinalysis should be done monthly, thyroid stimulating hormone and weight every three months (Level B; I) $(93,94)$. Pregnancy tests must be done regularly. The common laboratory abnormalities requiring intervention are anemia and neutropenia. The manufacturers recommend that dose reduction of ribavirin is required for hemoglobin levels below $100 \mathrm{~g} / \mathrm{L}$, and discontinuation is required if the hemoglobin level falls below $85 \mathrm{~g} / \mathrm{L}(95,96)$. The manufacturers also suggest that if the neutrophil count falls below $0.8 \times 10^{9} / \mathrm{L}$, the dose of interferon should be reduced. However, studies (97) suggest that even at neutrophil counts of $0.5 \times 10^{9} / \mathrm{L}$, infection is rare. The effect of dose reduction on SVR has not been fully evaluated. As long as patients receive more than $80 \%$ of the intended dose of all therapy, the reduction in SVR rates is small $(88,98)$.
For patients receiving less than $80 \%$ of the intended dose, but who continue on therapy, the SVR rate drops but remains acceptable. Patients who prematurely withdraw from therapy have very low SVR rates. For patients with ribavirin-induced anemia, erythropoietin can be used to maintain hemoglobin concentration (99). Studies show that the use of erythropoietin allows the ribavirin dose to be maintained. However, there are no data as yet on the effect that this might have on SVR rates. Granulocyte-macrophage colony stimulating factor and granulocyte colony stimulating factor (G-CSF) have been used to treat interferon-induced neutropenia. The use of erythropoietin and granulocyte-macrophage colony stimulating factor or G-CSF are controversial, and add significant expenses, but may be appropriate in some patients (100-102).

\section{Special situations}

Normal ALT: Approximately 30\% of HCV patients have persistently normal ALT (at least three normal ALT values when measured over a period of several months) (103-105). Although the majority of these patients have mild disease on biopsy, a few may have significant fibrosis (106-110). Treatment with peginterferon and ribavirin results in equivalent SVR rates in patients with normal ALT, compared with patients with abnormal ALT (111). Therefore, patients with persistently normal ALT should be considered for therapy (Level A; I). A liver biopsy is helpful to determine those with significant disease who would benefit from treatment, and will identify patients with mild disease, who may prefer to wait for newer therapies to be developed. In addition, other factors such as favourable genotype, infectivity concerns, severe symptoms, extrahepatic disease and occupational concerns should be considered in the decision to treat patients with normal ALT.

Cytopenias: Interferon and ribavirin therapy induces declines in red blood cells, white blood cells and platelet counts. In the past, patients whose baseline levels of red and white cells and platelets in blood were low were excluded from therapy. This included patients with thalassemia and constitutional neutropenia (common in blacks) (97). These patients should no longer be automatically refused treatment (Level C; II). Unacceptable declines in cell counts during therapy may respond to growth factor therapy (see above).

Acute HCV: Acute HCV is rarely identified because the majority of patients are asymptomatic during the initial stage of infection. Because some patients may present before the development of anti-HCV antibodies, the diagnosis requires the demonstration of HCV-RNA in serum (112). Approximately $40 \%$ to $50 \%$ of symptomatic patients (eg, those with jaundice, nausea, vomiting, right upper quadrant discomfort or influenza-like symptoms) will clear the virus spontaneously $(113,114)$. To avoid the unnecessary treatment of such patients, therapy should be deferred until three to four months following presentation if persistent HCV-RNA positivity is demonstrated (Level B; II) (115). In asymptomatic patients, immediate treatment can be considered due to the low probability of spontaneous viral clearance (114) and high rates of successful treatment when administered during the early period of infection (Level II) (115). Although data from randomized controlled trials are lacking, the highest rate of SVR (98\%) has been reported with high dose induction therapy with standard interferon monotherapy (five million units (MU) subcutaneously daily for four weeks followed by 5 MU subcutaneously TIW for 20 weeks) (Level B; II) (115). However, a large proportion of 
these patients were symptomatic so the efficacy of therapy in asymptomatic patients is unclear. The efficacy of combination therapy with ribavirin and the role of peginterferon-alpha has yet to be established, but may well be necessary in asymptomatic patients.

Cirrhosis: Although the majority of patients with chronic HCV have mild disease, a significant proportion will progress to cirrhosis. The majority of the complications of chronic $\mathrm{HCV}$, including liver failure, variceal bleeding and HCC, occur exclusively in these patients (116). Therefore, cirrhotic patients have the most to gain from successful antiviral therapy. Unfortunately, rates of SVR are lower and tolerance is generally poorer in patients with advanced disease. Treatment of patients with decompensated cirrhosis with interferon-based regimens is contraindicated outside specialized care environments due to the risk of precipitating severe liver failure and potential death (Level B; II) (117). In patients with compensated cirrhosis, the optimal therapy is the combination of peginterferon and ribavirin (Level B; II). Subgroup analyses of the large registration trials of this therapy revealed rates of SVR of $43 \%$ to $44 \%$ (in patients with bridging fibrosis and cirrhosis combined) $(87,88)$. The dosage and duration of therapy should be the same as in noncirrhotic patients; however, dosage reductions may be necessary in patients with pre-existing cytopenias. Adjunctive therapy with growth factors including erythropoietin and G-CSF may be useful in these patients, but data are limited. The role of maintenance interferon-based therapy is under study and cannot currently be recommended (Level D; III).

Extrahepatic manifestations of HCV: There are several conditions related to HCV that may require therapy, even in the absence of significant liver disease. These include cryoglobulinemia and glomerulonephritis. However, the treatment of these conditions has not been standardized. Neither the dose nor duration of therapy has been determined. Therefore, no recommendations can be made about how to treat these patients. However, such patients are probably best treated in specialized centres.

Retreatment of patients: Selected patients who have failed to respond to interferon-based therapy should be considered for retreatment. The decision to retreat patients should consider the previous therapy received, the tolerance of and response to prior treatment (nonresponse versus relapse), and factors predictive of an SVR. Patients with advanced fibrosis (stage 2 or greater) should be given priority for retreatment (Level C; II). 'Relapsers' become HCV-RNA-negative during treatment (as manifested by an EVR or end-of-treatment virological response), but have reappearance of HCV-RNA following the withdrawal of therapy. 'Nonresponders' fail to achieve HCVRNA negativity during treatment. The latter group is more resistant to retreatment with interferon-based regimens. In patients with a relatively good likelihood of response who have relapsed or not responded to interferon monotherapy, combination therapy with peginterferon-alpha and ribavirin at standard dosages and duration is the preferred retreatment strategy (Level B; II). In relapsers and nonresponders to interferon and ribavirin combination therapy, retreatment with peginterferonalpha and ribavirin can be considered, although efficacy data from randomized controlled trials are not currently available (Level III). Preliminary data suggest that approximately $10 \%$ of nonresponders and approximately $20 \%$ of relapsers achieve an SVR $(118,119)$. The optimal dose and duration of therapy has yet to be identified, although patients should receive at least the minimum therapy recommended for treatment-naïve patients. Renal impairment and renal transplantation: Peginterferonalpha-2b is relatively contraindicated in patients with a creatinine clearance below $50 \mathrm{~mL} / \mathrm{min}$ because peginterferonalpha-2b is excreted by the kidney (95). Peginterferon-alpha-2a can be administered at full dosage $(180 \mu \mathrm{g} /$ week $)$ in patients with a creatinine clearance above $20 \mathrm{~mL} / \mathrm{min}$, and a reduced dosage $(135 \mu \mathrm{g} /$ week $)$ in those with more severe renal dysfunction (96). Ribavirin is contraindicated in patients with significant renal dysfunction (creatinine clearance below $50 \mathrm{~mL} / \mathrm{min}$ ) due to altered pharmacokinetics and the risk of severe anemia. Ribavirin has been used, however, in specialized care centres at low dosages with therapeutic monitoring of plasma ribavirin concentration (120). In patients with previous renal transplantation, interferon is contraindicated due to the risk of precipitating irreversible graft dysfunction (Level II) (121).

Children with chronic HCV: Although the progression of chronic HCV appears slower in children than in adults (122), some children have significant fibrosis on liver biopsy (Level II). These findings suggest that antiviral treatment may be warranted in selected patients; however, the indications for therapy are poorly defined. As in adults, the decision for treatment must consider the efficacy and adverse effects of therapy and the severity of the underlying liver disease. Children with $\mathrm{HCV}$ are typically asymptomatic and the majority have normal or minimally elevated serum aminotransferases (Level II) (123). Because the correlation between ALT and hepatic histological lesions is poor, a liver biopsy should be considered in the management of infected children, particularly after 10 years of infection (Level C; III). Patients with moderate to severe fibrosis and/or necroinflammatory activity on liver biopsy should be targeted for therapy, preferably at specialized centres (Level C; III). Standard interferon $\left(3 \mathrm{MU} / \mathrm{m}^{2} \mathrm{TIW}\right)$ and ribavirin $(15 \mathrm{mg} / \mathrm{kg} /$ day $)$ for 48 weeks yields rates of SVR similar to that observed in adults (40\% to $60 \%$ overall, $70 \%$ to $100 \%$ in genotypes 2 and 3) (Level II) (124,125). The efficacy of peginterferon and ribavirin has yet to be conclusively demonstrated. Interferon is generally well-tolerated in children; weight loss, the only side effect, presents more frequently in children than in adults. The resultant growth inhibition is not permanent (126). Children younger than three years of age should not be treated due to concerns regarding the potential neurotoxicity of interferon on the developing brain (127) and the higher rates of spontaneous viral clearance observed in this subgroup.

\section{HIV-HCV COINFECTION}

Approximately one-quarter of Canadian HIV-infected individuals are seropositive for HCV (128). Among HIV seropositive injection drug users, this rate is at least $50 \%$ and up to $80 \%$ in some regions (129). Since the introduction of HAART, liver disease secondary to $\mathrm{HCV}$ infection has become a leading cause of morbidity and mortality in HIV-HCV coinfection (130). Progression to cirrhosis and decompensated liver disease is accelerated in HIV-HCV coinfected patients (131-133).

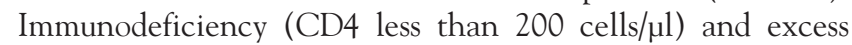
alcohol consumption (greater than $50 \mathrm{~g} /$ day) are independently associated with rapid progression to cirrhosis. The influence of HCV on HIV infection is less pronounced $(134,135)$. CD4 $\mathrm{T}$ cell recovery following initiation of HAART may be blunted in comparison with HCV seronegative individuals with HIV 
$(136,137)$. Mildly elevated aminotransferases, biopsy inflammation scores and liver fibrosis may be improved in HIV-HCV coinfected subjects receiving potent and durable HAART, compared with baseline $(138,139)$.

\section{Screening and investigations}

$\mathrm{HCV}$ screening by serology is recommended in all HIV-infected individuals (Level B; II). HCV-RNA testing by PCR should be done in the setting of patients who are anti-HCV negative but at high risk of HCV (eg, patients with abnormal liver enzymes in the absence of other causes of liver disease or patients at high risk for acquiring HCV infection). Liver biopsies in HIV$\mathrm{HCV}$ coinfection identify at least some disease activity in most patients (greater than 95\%) (140). In one study, three-quarters of HIV-HCV coinfected subjects were found to have METAVIR stage 2 or 3 fibrosis, and $10 \%$ were cirrhotic. A biopsy is strongly recommended to stage fibrosis, assist in the decision regarding the need for drug therapy, predict the likelihood of response to therapy and identify cirrhotic patients who may be at more risk of treatment-related hepatotoxicity (Level A; II).

\section{Treatment environment}

The management of HIV-HCV coinfection is more complex than the management of either disease alone. Therefore, a coordinated multidisciplinary approach for the delivery of care is strongly recommended (Level C; II).

\section{HCV drug therapy}

A decision to initiate therapy should be based on similar criteria to that used in HCV monoinfected individuals (Level A; I). Because HCV progresses more rapidly in HIV-HCV coinfected patients, treatment may be considered in those with minimal fibrosis (eg, stage 1) and/or normal ALT (Level C; II).

The SVR rate with 48 weeks of peginterferon-alpha-2 plus ribavirin for genotype 1 infection is under 30\% (Level I) (140. 144). The SVR rate with 48 weeks treatment for genotype 2 and 3 infection may be as high as $62 \%$, with low virological relapse rates between the end of therapy and the 72 week follow-up (Level I) (141-143). It is unclear if 24 weeks of therapy is sufficient, because a $29 \%$ relapse rate has been reported after the end of therapy for genotype 3 infections (140). The EVR, defined as at least a 2 log drop in HCV viral load, should be determined because the lack of an EVR predicts failure to achieve SVR (Level A; I). Given the low rates of SVR, HCV therapy should be initiated using the full recommended doses of interferon and ribavirin with aggressive supportive therapy for drug-induced side effects because SVR rates are reduced with subtherapeutic dosing in $\mathrm{HCV}$ monoinfected patients (Level B; II).

The constitutional and cognitive toxicities related to therapy are significant (144), but in general, are not more frequent or severe in comparison with those infected with HIV alone. Therapy in this population is often contraindicated because of comorbid illnesses such as psychiatric illness, severe cytopenias and uncontrolled substance abuse. Severe adverse interactions between antiretrovirals and HCV drug therapy occur rarely and can usually be prevented by careful laboratory monitoring and avoiding combinations of certain medications. Caution should be exercised when didanosine and ribavirin are used in combination because of the risk of mitochondrial toxicity (lactic acidosis and pancreatitis) (Level I) (145-147).
Because both zidovudine and ribavirin can cause anemia, careful attention is warranted if coadministered (Level C; II) (148). Although ribavirin may alter the intracellular levels of several NRTIs (149), neither increased treatment side effects nor loss of HIV virological suppression have been reported in NRTI-treated subjects initiating ribavirin.

\section{Use of antiretrovirals}

There is a risk of hepatotoxicity with antiretroviral therapy $(150,151)$. Hepatic steatosis and fulminant hepatitis are rare complications of HIV NRTI treatment (151-155). These toxicities are mediated by NRTI inhibition of mitochondrial DNA replication (152). Severe elevation of aminotransferases (defined as greater than $10 \times \mathrm{ULN}$ ) occurs in $5 \%$ to $10 \%$ of patients; most protease inhibitors (153-155) are usually asymptomatic and resolve without interruption of antiretroviral therapy. However, the patient should be monitored closely for signs of liver failure. A $2 \%$ to $4 \%$ incidence of rise in aminotransferases is reported in treatment-naïve subjects receiving non-NRTIs (152). An early nevirapine hypersensitivity syndrome consisting of fever, rash and elevated ALT has also been described but is infrequently observed $(155,156)$. Treatmentlimiting hepatotoxicity is rare with all classes of antiretrovirals $(157,158)$.

\section{Which therapy first}

In cases in which CD4 $\mathrm{T}$ lymphocyte count is below 200 cells $/ \mu L$, HAART represents the most beneficial initial intervention in those with HIV-HCV coinfection (Level III). In cases in which the CD4 T lymphocyte count has never fallen below $350 \times 10^{9}$ cells/L, the strategy of first treating HCV and then HIV to avoid the combined toxicities of coadministration of these medications may be considered (Level C; III). In those with CD4 $\mathrm{T}$ cell count between $200 \times 10^{9}$ cells/L and $350 \times 10^{9}$ cells/L, there may be cases in which HAART can be deferred in favour of initial HCV therapy. This is reasonable in the absence of opportunistic infection and markers of rapidly progressive HIV disease (eg, high HIV viral load). Initiation of both therapies simultaneously is not recommended, given the potential for combined toxicity (Level D; III).

\section{Adjuvant therapy}

Although there may be situations in which adjunctive therapies including, pre-HCV drug therapy antidepressants and erythropoietin, may be of value in improving quality of life (159), additional scientific data to support the efficacy of these interventions in HIV-HCV coinfection are required. Management of injection drug use, alcohol use and depression should be optimized before initiating HCV drug therapy because these negatively impact therapeutic success (Level C; II).

\section{Transplantation}

Liver transplantation for HIV-HCV coinfected subjects with liver failure is being evaluated in a research setting. Further research into the efficacy and safety of this therapeutic option is required. Patients with liver failure should be assessed individually and referred for transplantation, if appropriate.

\section{Vaccination}

HAV and HBV vaccination are recommended (Level C; II). 


\section{CONCLUSIONS}

The management of chronic viral hepatitis is complex, whether it be HBV or HCV. There are insufficient hepatologists, gastroenterologists and infectious disease specialists in Canada to allow all patients to receive specialist care. It is therefore incumbent on nonspecialists caring for these populations to familiarize themselves with the contents of this document, to recognize the limitations of their knowledge, and to refer patients for specialist attention when required.
Only in this manner will the population with chronic viral hepatitis in Canada receive the care they deserve.

ACKNOWLEDGEMENTS: The authors would like to thank Dr David Wong, Dr Steve Shafran and Dr Marina Klein, who provided the very latest information about the efficacy of anti-HCV therapy in HIV coinfected patients after the conference and as soon as it was available.

\section{REFERENCES}

1. Sherman M. Management of viral hepatitis: Clinical and public health perspectives-a consensus statement. CASL Hepatitis Consensus Group. Canadian Association for Study of the Liver. Can J Gastroenterol 1997;11:407-16.

2. Anonymous. Canadian consensus conference on the management of viral hepatitis. Can J Gastroenterol 2000;14(Suppl B):5B-20.

3. Management guidelines for the HCV and HIV co-infected adult: Recommendations of a multidisciplinary expert panel. Can J Infect Dis 2001;12(Suppl A):8A-21A,

4. Kish MA; Infectious Diseases Society of America. Guide to development of practice guidelines. Clin Infect Dis 2001;32:851-4.

5. Ni YH, Chang MH, Huang LM, et al. Hepatitis B virus infection in children and adolescents in a hyperendemic area: 15 years after mass hepatitis B vaccination. Ann Int Med 2001;135:796-800.

6. Da Villa G, Piccinino F, Scolastico C, Fusco M, Piccinino R, Sepe A. Long-term epidemiological survey of hepatitis $B$ virus infection in a hyperendemic area (Afragola, southern Italy): Results of a pilot vaccination project. Res Virol 1998;149:263-70.

7. Sherman M, Peltekian KM, Lee C. Screening for hepatocellular carcinoma in chronic carriers of hepatitis B virus: Incidence and prevalence of hepatocellular carcinoma in a North American urban population. Hepatology 1995;22:432-8.

8. Hurie MB, Mast EE, Davis JP. Horizontal transmission of hepatitis B virus infection to United States-born children of Hmong refugees. Pediatrics 1992;89:269-73.

9. Mahoney FJ, Lawrence M, Scott C, Le Q, Lambert S, Farley TA. Continuing risk for hepatitis $\mathrm{B}$ virus transmission among Southeast Asian infants in Louisiana. Pediatrics 1995;96:1113-6.

10. Hsu HM, Chen DS, Chuang CH, et al. Efficacy of a mass hepatitis B vaccination program in Taiwan. Studies on 3464 infants of hepatitis B surface antigen-carrier mothers. JAMA 1988;260:2231-5.

11. Zanetti AR, Dentico P, Del Vecchio, et al. Multicentre trial on the efficacy of HBIG and vaccine in preventing perinatal hepatitis B. Final report. J Med Virol 1986;18:327-34.

12. Beasley RP, Trepo C, Stevens CE, Szmuness W. The e antigen and vertical transmission of hepatitis B surface antigen. Am J Epidemiol 1977;105:94-8.

13. Anderson KE, Stevens CE, Tsuei JJ, Lee WC, Sun SC, Beasley P. Hepatitis $\mathrm{B}$ antigen in infants born to mothers with chronic hepatitis B antigenemia in Taiwan. Am J Dis Child 1975;129:1389-92.

14. Krahn M, Guasparini R, Sherman M, Detsky AS. Costs and costeffectiveness of a universal, school-based hepatitis $B$ vaccination program. Am J Public Health 1998;88:1638-44

15. Fukuda R, Ishimura N, Hamamoto S, et al. Co-infection by serologically-silent hepatitis $\mathrm{B}$ virus may contribute to poor interferon response in patients with chronic hepatitis $\mathrm{C}$ by downregulation of type-I interferon receptor gene expression in the liver. J Med Virol 2001;63:220-7.

16. Vento S, Garofano T, Renzini C, et al. Fulminant hepatitis associated with hepatitis A virus superinfection in patients with chronic hepatitis C. N Engl J Med 1998;338:286-90.

17. Keeffe EB, Iwarson S, McMahon BJ, et al. Safety and immunogenicity of hepatitis A vaccine in patients with chronic liver disease. Hepatology 1998;27:881-6.

18. Bruix J, Sherman M, Llovet JM, et al. Clinical management of hepatocellular carcinoma. Conclusions of the Barcelona-2000 EASL conference. J Hepatol 2001;35:421-30.

19. Lok AS, Heathcote EJ, Hoofnagle JH. Management of hepatitis B: 2000 - summary of a workshop. Gastroenterology 2001;120:1828-53.

20. De Franchis R, Meucci G, Vecchi M, et al. The natural history of asymptomatic hepatitis B surface antigen carriers. Ann Int Med 1993;118:191-4.

21. Hsu YS, Chien RN, Yeh CT, et al. Long-term outcome after spontaneous $\mathrm{HBeAg}$ seroconversion in patients with chronic hepatitis B. Hepatology 2002;35:1522-7.

22. Santagostino E, Colombo M, Rivi M, et al. A 6-month versus a 12 -month surveillance for hepatocellular carcinoma in 559 hemophiliacs infected with the hepatitis $C$ virus. Blood 2003;102:78-82.

23. Trevisani F, De NS, Rapaccini G, et al. Semiannual and annual surveillance of cirrhotic patients for hepatocellular carcinoma: Effects on cancer stage and patient survival (Italian experience). Am J Gastro 2002;97:734-44.

24. Manesis EK, Papatheodoridis GV, Hadziyannis SJ. Serum HBV-DNA levels in inactive hepatitis B virus carriers. Gastroenterology 2002;122:2092-3.

25. Fattovich G, Giustina G, Sanchez-Tapias J, et al. Delayed clearance of serum HBsAg in compensated cirrhosis B: Relation to interferon alpha therapy and disease prognosis. European Concerted Action on Viral Hepatitis (EUROHEP). Am J Gastroenterol 1998;93:896-900.

26. Perrillo RP, Lai CL, Liaw YF, et al. Predictors of HBeAg loss after lamivudine treatment for chronic hepatitis B. Hepatology 2002;36:186-94.

27. Brunetto MR, Oliveri F, Colombatto P, et al. Treatment of HBeAgnegative chronic hepatitis $\mathrm{B}$ with interferon or pegylated interferon. J Hepatol 2003;39(Suppl 1):S164-7.

28. Hoofnagle JH. Challenges in therapy of chronic hepatitis B. J Hepatol 2003;39(Suppl 1):S230-5.

29. Perrillo RP, Schiff ER, Davis GL, et al. A randomized, controlled trial of interferon alfa-2b alone and after prednisone withdrawal for the treatment of chronic hepatitis B. The Hepatitis Interventional Therapy Group. N Engl J Med 1990;323:295-301.

30. Brook MG, Chan G, Yap I, et al. Randomized controlled trial of lymphoblastoid interferon alfa in Europid men with chronic hepatitis B virus infection. BMJ 1989;299:652-6.

31. Wong DK, Yim C, Naylor CD, et al. Interferon alfa treatment of chronic hepatitis B: Randomized trial in a predominantly homosexual male population. Ann Intern Med 1993;119:312-23.

32. Van Nunen AB, Hansen BE, Suh DJ, et al. Durability of HBeAg seroconversion following antiviral therapy for chronic hepatitis $B$ : Relation to type of therapy and pretreatment serum hepatitis B virus DNA and alanine aminotransferase. Gut 2003;52:420-4.

33. Janssen HL, Gerken G, Carreno V, et al. Interferon alfa for chronic hepatitis B infection: Increased efficacy of prolonged treatment. Hepatology 1999;30:238-43.

34. Tine F, Liberati A, Craxi A, et al. Interferon treatment in patients with chronic hepatitis B: A meta-analysis of the published literature. J Hepatol 1993;18:154-62.

35. Song BC, Suh DJ, Lee HC, et al. Which patients with chronic hepatitis B are more likely to relapse after interferon alpha-induced hepatitis B e antigen loss in Korea? J Clin Gastro 2004;38:124-9.

36. Yuen MF, Hui CK, Cheng CC, Wu CH, Lai YP, Lai CL. Long-term follow-up of interferon alfa treatment in Chinese patients with chronic hepatitis B infection: The effect on hepatitis B e antigen seroconversion and the development of cirrhosis-related complications. Hepatology 2001;34:139-45.

37. Niederau C, Heintges T, Lange S, et al. Long-term follow-up of $\mathrm{HBeAg}$-positive patients treated with interferon alfa for chronic hepatitis B. N Engl J Med 1996;334:1422-7.

38. Lin SM. Sheen IS, Chien RN, et al. Long-term beneficial effect of interferon therapy in patients with chronic hepatitis B virus infection. Hepatology 1999;29:971-5. 
39. Lampertico P, Del Ninno E, Vigano M, et al. Long-term suppression of hepatitis $B$ e antigen-negative chronic hepatitis B by 24-month interferon therapy. Hepatology 2003;37:756-63.

40. Manesis EK, Hadziyannis SJ. Interferon alpha treatment and retreatment of hepatitis B e antigen-negative chronic hepatitis B. Gastroenterology 2001;121:101-9.

41. Papatheodoridis GV, Manesis E, Hadziyannis SJ. The long-term outcome of interferon-alpha treated and untreated patients with HBeAg-negative chronic hepatitis B. J Hepatol 2001;34:306-13.

42. Lai CL, Chien RN, Leung NW, et al. A one-year trial of lamivudine for chronic hepatitis B. Asia Hepatitis Lamivudine Study Group. N Engl J Med 1998;339:61-8.

43. Dienstag JL, Schiff ER, Wright TL, et al. Lamivudine as initial treatment for chronic hepatitis B in the United States. N Engl J Med 1999;341:1256-63.

44. Schalm SW, Heathcote J, Cianciara J, et al. Lamivudine and alpha interferon combination treatment of patients with chronic hepatitis B infection: A randomized trial. Gut 2000;46:562-8.

45. Song BC, Suh DJ, Lee HC, et al. Hepatitis B e antigen seroconversion after lamivudine therapy is not durable in patients with chronic hepatitis B in Korea. Hepatology 2000;32:803-6.

46. Hunt CM, McGill JM, Allen MI, Condreay LD. Clinical relevance of hepatitis B viral mutations. Hepatology 2000;31:1037-44.

47. Leung NW, Lai CL, Chang TT, et al. Extended lamivudine treatment in patients with chronic hepatitis B enhances hepatitis B e antigen seroconversion rates: Results after three years of therapy. On behalf of the Asia Hepatitis Lamivudine Study Group. Hepatology 2001;33:1527-32.

48. Lok AS, Lai CL, Leung N, et al. Long-term safety of lamivudine treatment in patients with chronic hepatitis B. Gastroenterology 2003;125:1714-22.

49. Tassopoulos NC, Volpes R, Pastore G, et al. Efficacy of lamivudine in patients with hepatitis $\mathrm{B}$ e antigen-negative/hepatitis $\mathrm{B}$ virus DNA-positive (pre-core mutant) chronic hepatitis B. Lamivudine Precore Mutant Study Group. Hepatology 1999;29:889-96.

50. Santantonio T, Mazzola M, Iacovazzi T, et al. Long-term followup of patients with anti-HBe/HBV DNA-positive chronic hepatitis B treated for 12 months with lamivudine. J Hepatol 2000;32:300-6

51. Schiff ER, Dienstag JL, Karayalcin S, et al. Lamivudine and 24 weeks of lamivudine/interferon combination therapy for hepatitis B e antigen-positive chronic hepatitis B in interferon non-responders. J Hepatol 2003;38:818-26.

52. Hadziyannis SJ, Tassopoulos NC, Heathcote EJ, et al. Adefovir dipivoxil for the treatment of hepatitis $\mathrm{B}$ e antigen-negative chronic hepatitis B. N Engl J Med 2003;348:800-7.

53. Marcellin P, Chang TT, Lim SG, et al. Adefovir dipivoxil for the treatment of hepatitis B e antigen-positive chronic hepatitis B. N Engl J Med 2003;348:808-16.

54. Perrillo R, Hann HW, Mutimer D, et al. Adefovir dipivoxil added to ongoing lamivudine in chronic hepatitis B with YMDD mutant hepatitis B virus. Gastroenterology 2004;126:81-90.

55. Angus P, Vaughan R, Xiong S, et al. Resistance to adefovir dipivoxil therapy associated with the selection of a novel mutation in the HBV polymerase. Gastroenterology 2003;125:292-7.

56. Cooksley WG, Piratvisuth T, Lee SD, et al. Peginterferon alpha-2a (40 kDA): An advance in the treatment of hepatitis B e antigenpositive chronic hepatitis B. J Viral Hepatol 2003;10:298-305.

57. McMahon BJ, Holck P, Bulkow L, Snowball M. Serologic and clinical outcomes of 1,563 Alaska natives chronically infected with hepatitis B virus. Ann Int Med 2001;135:759-68

58. Bortolotti F, Cadrobbi P, Crivellaro C, et al. Long-term outcome of chronic type $\mathrm{B}$ hepatitis in patients who acquire hepatitis $\mathrm{B}$ virus infection in childhood. Gastroenterology 1990;99:805-10.

59. Lok ASF, Lai CL. A longitudinal follow-up of asymptomatic hepatitis B surface antigen-positive Chinese children. Hepatology 1988;8:1130-3

60. Evans AA, Fine M, London WT. Spontaneous seroconversion in hepatitis B e antigen-positive chronic hepatitis B: Implications for therapy. J Clin Infect Dis 1997;176:845-50.

61. Marx G, Martin SR, Chicoine JF, Alvarez F. Long-term follow-up of chronic hepatitis B virus infection in children of different ethnic origin. J Infect Dis 2002;186:295-301.

62. Sokal EM, Conjeevaram HS, Roberts EA, et al. Interferon alfa therapy for chronic hepatitis B in children: A multinational randomized controlled trial. Gastroenterology 1998;114:988-95.
63. Jonas MM, Kelley DA, Mizerski J, et al. Clinical trial of lamivudine in children with chronic hepatitis B. N Engl J Med 2002;346:1706-13.

64 Van Zonneveld M. van Nunen A, Niesters HG, et al. Lamivudine treatment during pregnancy to prevent perinatal transmission of hepatitis B virus infection. J Viral Hepatol 2003;10:294-7.

65. Villeneuve JP, Condreay LD, Willems B, et al. Lamivudine treatment for decompensated cirrhosis resulting from chronic hepatitis B. Hepatology 2000;31:207-10.

66. Fontana RJ, Hann HW, Perrillo HP, et al. Determinants of early mortality in patients with decompensated chronic hepatitis B treated with antiviral therapy. Gastroenterology 2002;123:719-27.

67. Ben-Ari Z, Broida E, Kittai Y, et al. An open-label study of lamivudine for chronic hepatitis B in six patients with chronic renal failure before and after kidney transplantation. Am J Gastroenterol 2000;95:3579-83.

68. Lau GK, He ML, Fong DY, et al. Preemptive use of lamivudine reduces hepatitis $\mathrm{B}$ exacerbation after allogeneic hematopoietic cell transplantation. Hepatology 2002;36:702-9.

69. Nagler A, Ilan Y, Adler R, et al. Successful immunization of autologous bone marrow transplantation recipients against hepatitis B virus by active vaccination. Bone Marrow Transplant 1995;1:475-8

70. Remis RS, Dufour A, Alary M, et al. Association of hepatitis B virus infection with other sexually transmitted infections in homosexual men. Omega Study Group. Am J Public Health 2000;90:1570-4.

71. Colin JF, Cazals-Hatem D, Loriot MA, et al. Influence of human immunodeficiency virus infection on chronic hepatitis B in homosexual men. Hepatology 1999;29:1306-10.

72. Gilson RJ, Hawkins AE, Beecham MR, et al. Interactions between HIV and hepatitis B virus in homosexual men: Effects on the natural history of infection. AIDS 1997;11:597-606.

73. Scolfaro C, Fiammengo P, Balbo L, et al. Hepatitis B vaccination in HIV-1-infected children: Double efficacy doubling the paediatric dose. AIDS 1996;10:1169-70.

74. Wong EK, Bodsworth NJ, Slade MA, et al. Response to hepatitis B vaccination in a primary care setting: Influence of HIV infection, CD4+ lymphocyte count and vaccination schedule. Int J STD AIDS 1996;7:490-4.

75. Kaplan JE, Masur H, Holmes KK. Guidelines for preventing opportunistic infections among HIV-infected persons - 2002. Recommendations of the U.S. Public Health Service and the Infectious Diseases Society of America. MMWR Recomm Rep 2002;51(RR-8):1-52.

76. Notice to Readers Update: Recommendations to prevent hepatitis B virus transmission - United States. MMWR Recomm Rep 1995;44:574-5.

77. Cooper D, Gore D, Pozniak AL, et al. Tenofovir disoproxil fumarate and lamivudine combination therapy compared to lamivudine alone for HBV in therapy-naïve HIV/HBV co-infected patients: 48 week interim results. In: 10th Conference on Retroviruses and Opportunistic Infections, 2003 February 10-14, 2003, Boston, MA, 2003. (Abst)

78. Da Silva LC, Pinho JR, Sitnik R, Da Fonseca LE, Carrilho FJ. Efficacy and tolerability of long-term therapy using high lamivudine doses for the treatment of chronic hepatitis B. J Gastroenterol 2001;36:476-85.

79. Benhamou Y, Bochet M, Thibault V, et al. Long-term incidence of hepatitis $B$ virus resistance to lamivudine in human immunodeficiency virus-infected patients. Hepatology 1999;30:1302-6.

80. Cooper D, Coakley DF, Sayre J, et al. Anti-hepatitis B virus (HBV) activity of tenofovir disoproxil fumarate (TDF) in lamivudine (LAM) experienced HIV/HBV co-infected patients. Abstract 6015. In: XIV International AIDS Conference, 2002 July 7-12, 2002, Barcelona, Spain, 2002.

81. Bochet M, Tubiana R, Benhamou Y, et al. Tenofovir disoproxil fumarate suppresses lamivudine-resistant HBV replication in patients co-infected with HIV/HBV. Abstract 675-M. In: 9th Conference on Retroviruses and Opportunistic Infections, 2002. February 24-28, 2003, Seattle, Washinton, 2002.

82. Maio G, d'Argenio P, Stroffolini T, et al. Hepatitis $C$ virus infection and alanine aminotransferase levels in the general population: A survey in a southern Italian town. J Hepatol 2000;33:116-20. 
83. Comandini UV, Tossini G, Longo MA, et al. Sporadic hepatitis C virus infection: A case-control study of transmission routes in a selected hospital sample of the general population in Italy. Scand J Infect Dis 1998;30:11-5.

84. McHutchison JG, Poynard T, Esteban-Mur R, et al. Hepatic HCV RNA before and after treatment with interferon alone or combined with ribavirin. Hepatology 2002;35:688-93.

85. Davis GL, Esteban-Mur R, Rustgi V, et al. Interferon alfa-2b alone or in combination with ribavirin for the treatment of relapse of chronic hepatitis C. N Engl J Med 1998;339:1493-9.

86. Marcellin P, Boyer N, Gervais A, et al. Long-term histologic improvement and loss of detectable intrahepatic HCV RNA in patients with chronic hepatitis $\mathrm{C}$ and sustained response to interferon-alpha therapy. Ann Intern Med 1997;127:875-81.

87. Manns MP, McHutchison JG, Gordon SC, et al. Peginterferon alfa-2b plus ribavirin compared with interferon alfa- $2 \mathrm{~b}$ plus ribavirin for initial treatment of chronic hepatitis C: A randomized trial. Lancet 2001;358:958-65.

88. Fried MW, Shiffman ML, Reddy R, et al. Peginterferon alfa-2a plus ribavirin for chronic hepatitis $\mathrm{C}$ virus infection. $\mathrm{N}$ Engl J Med 2002;347:975-82

89. Hadziyannis SJ, Cheinquer H, Morgan T, et al. Peginterferon alfa 2a (40KD) (Pegasys) in combination with ribavirin (RBV): Efficacy and safety results from a phase III randomized double-blind multicentre study examining effect of duration of treatment and RBV dose. J Hepatol 2002;36(Suppl 1):3

90. Bedossa P, Poynard T. An algorithm for the grading of activity in chronic hepatitis C. The METAVIR Cooperative Study Group. Hepatology 1996;24:289-93.

91. Davis GL, Wong JB, McHutchison JG, et al. Early virologic response to treatment with peginterferon alfa- $2 \mathrm{~b}$ plus ribavirin in patients with chronic hepatitis C. Hepatology 2003;38:645-52.

92. Shobokshi OA, Serebour FE, Skakni L, et al. Week 12 EVR predicts EOT in CHC genotype 4 patients treated with peginterferon alfa $2 \mathrm{a}$ (40kD)/RBV. J Hepatol 2003;38(Suppl 2):172.

93. Seeff LB, Hoofnagle JH. National Institutes of Health Consensus Development Conference: Management of hepatitis C: 2002. Hepatology 2002;36(Suppl 1):S1-2.

94. EASL International Consensus Conference on hepatitis C. Paris, 26-27 February 1999. Consensus statement. J Hepatol 1999;31(Suppl 1):3-8.

95. Unitron Peg (Peginterferon alfa-2b) package insert. Schering Canada. 2003

96. Pegasys (Peginterferon alfa-2a) Product Monograph. Hoffman LaRoche Limited, 2003. <http://www.rocheusa.com/products/ pegasys/pi.pdf> (Version current at November 8, 2004).

97. Soza A, Everhart JE, Ghany MG, et al. Neutropenia during combination therapy of interferon alfa and ribavirin for chronic hepatitis C. Hepatology 2002;36:1273-9.

98. McHutchison JG, Manns M, Patel K, et al. Adherence to combination therapy enhances sustained response in genotype-1infected patients with chronic hepatitis C. Gastroenterology 2002;123:1061-9.

99. Dieterich DT, Wasserman R, Brau N, et al. Once-weekly epoetin alfa improves anemia and facilitates maintenance of ribavirin dosing in hepatitis $\mathrm{C}$ virus-infected patients receiving ribavirin plus interferon alfa. Am J Gastroenterol 2003;98:2491-9.

100. Koliouskas D, Sidiropuolos I, Masmanidou M, et al. Comparative analysis and effect of GM-CSF on neutropenia in peg-interferon alpha-2b and ribavirin treated chronic hepatitis $\mathrm{C}$ patients. Hepatology 2002;36:587.

101. Carey E, Rosati M, Anderson M, et al. Use of G-CSF allows for optimal PEG-INF dosing during therapy for hepatitis $\mathrm{C}$ virus with pegylated interferon and ribavirin. Hepatology 2002;36:604.

102. Gronbaek K, Krarup HB, Ring-Larsen H, et al. Interferon alfa-2b alone or combined with recombinant granulocyte-macrophage colony-stimulating factor as treatment of chronic hepatitis C. Scand J Gastroenterol 2002;37:840-4.

103. Marcellin P, Levy S, Erlinger S. Therapy of hepatitis C: Patients with normal aminotransferases levels. Hepatology 1997;23(Suppl 1):133S-6.

104. Tassopoulos NC. Treatment in patients with normal ALT levels. J Hepatol 1999;31(Suppl 1):193-6.

105. Bacon BR. Treatment of patients with Hepatitis C and normal serum aminotransferase levels. Hepatology 2002;36:S179-84
106. Mathurin P, Moussalli J, Cadranel J, et al. Slow progression rate of fibrosis in hepatitis $\mathrm{C}$ virus patients with persistently normal alanine aminotransferase activity. Hepatology 1998;27:868-72.

107. Jamal M, Soni A, Quinn PG, et al. Clinical features of hepatitis Cinfected patients with persistently normal alanine aminotransferase levels in the Southwestern United States. Hepatology 1999;30:1307-11.

108. Hui C, Belaye T, Montegrande K, Wright TL. A comparison in the progression of liver fibrosis in chronic hepatitis $\mathrm{C}$ between persistently normal and elevated aminotransferases. J Hepatol 2003;38:511-7.

109. Persico M, Persico E, Suozzo R, et al. Natural history of hepatitis C virus carriers with persistently normal aminotransferase levels. Gastroenterology 2000;118:760-4

110. Cividini A, Rebucci C, Silini E, Mondelli MU. Is the natural history of hepatitis $\mathrm{C}$ virus carriers with normal aminotransferase really benign? Gastroenterology 2001;121:1526-7.

111. Zeuzem S, Diago M, Gane E, et al. International multicentre randomized, controlled study for the treatment of patients with chronic hepatitis $\mathrm{C}$ and persistently normal ALT levels with peginterferon alfa-2a (40KD) (Pegasys) and ribavirin (Copegus). Hepatology 2003;38(Suppl 1):208A.

112. Orland JR, Wright TL, Cooper S. Acute hepatitis C. Hepatology 2001;33:321-7.

113. Villano SA, Vlahov D, Nelson KE, et al. Persistence of viremia and the importance of long-term follow-up after acute hepatitis C infection. Hepatology 1999;29:908-14.

114. Gerlach JT, Diepolder HM, Zachoval R, et al. Acute hepatitis C: High rate of both spontaneous and treatment-induced viral clearance. Gastroenterology 2003;125:80-8.

115. Jaeckel E, Cornberg M, Wedemeyer $\mathrm{H}$, et al. Treatment of acute hepatitis C with interferon alfa-2b. N Engl J Med 2001;345:1452-7.

116. Fattovich G, Giustina G, Degos G, et al. Morbidity and mortality in compensated cirrhosis type C: A retrospective follow-up study of 384 patients. Gastroenterology 1997;112:463-72.

117. Crippin JS, McCashland T, Terrault N, et al. A pilot study of the tolerability and efficacy of antiviral therapy in hepatitis $\mathrm{C}$ virusinfected patients awaiting liver transplantation. Liver Transplantation 2002;8:350-5

118. Shiffman M. Retreatment of HCV non-responders with peginterferon and ribavirin: Results from the lead-in phase of the Hepatitis C Antiviral Long-term Treatment against Cirrhosis (HALT-C) trial. Hepatology 2002;36(Pt 2):295A.

119. Jacobsen I, Russo MW, Brown RS, et al. Pegylated interferon alfa-2b plus ribavirin in patients with chronic hepatitis $\mathrm{C}$ : A trial in prior non-responders to interferon monotherapy or combination therapy and in combination therapy relapsers. Gastroenterology 2002;122:A626.

120. Bruchfeld A, Stahle L, Andersson J, Schvarcz R. Ribavirin treatment in dialysis patients with chronic hepatitis $\mathrm{C}$ virus infection - a pilot study. J Viral Hepatitis 2001;8:287-92

121. Gane E, Pilmore H. Management of chronic viral hepatitis before and after renal transplantation. Transplantation 2002;74:427-37.

122. Vogt M, Lang T, Frosner G, et al. Prevalence and clinical outcome of hepatitis $\mathrm{C}$ infection in children who underwent cardiac surgery before the implementation of blood-donor screening. $\mathrm{N}$ Engl J Med 1999;341:866-70

123. Bortolotti F, Jara P, Diaz C, et al. Posttransfusion and communityacquired hepatitis $\mathrm{C}$ in childhood. J Pediat Gastroenterol Nutr 1994;18:279-83.

124. Lackner H, Moser A, Deutsch J, et al. Interferon-alpha and ribavirin in treating children and young adults with chronic hepatitis C after malignancy. Pediatrics 2000;106:E53.

125. Wirth S, Lang T, Gehring S, Gerner P. Recombinant alfainterferon plus ribavirin therapy in children and adolescents with chronic hepatitis C. Hepatology 2002;36:1280-4.

126. Comanor L, Minor J, Conjeevaram HS, et al. Impact of chronic hepatitis B and interferon-alpha therapy on growth of children. J Viral Hepat 2001;8:139-47.

127. Barlow CF, Priebe CJ, Mulliken JB, et al. Spastic diplegia as a complication of interferon Alfa-2a treatment of hemangiomas of infancy. J Pediat 1998;132(3 Pt 1):527-30.

128. Remis RS. The Prevalence of hepatitis C in Canada. Submitted to Health Canada, 2003.

129. Thomas DL, Vlahov D, Solomon L, et al. Correlates of hepatitis C virus infections among injection drug users. Medicine (Baltimore) $1995 ; 74: 212-20$. 
130. Macias J, Melguizo I, Fernandez-Rivera FJ, et al. Mortality due to liver failure and impact on survival of hepatitis virus infections in HIV-infected patients receiving potent antiretroviral therapy. Eur J Clin Microbiol Infect Dis 2002;21:775-81.

131. Graham CS, Baden LR, Yu E, et al. Influence of human immunodeficiency virus infection on the course of hepatitis $C$ virus infection: A meta-analysis. Clin Infect Dis 2001;33:562-9.

132. Eyster ME, Diamondstone LS, Lien JM, et al. Natural history of hepatitis $\mathrm{C}$ virus infection in multitransfused hemophiliacs: Effect of co infection with human immunodeficiency virus. The Multicenter Hemophilia Cohort Study. J Acquir Immune Defic Syndr 1993;6:602-10.

133. Telfer P, Sabin C, Devereux H, et al. The progression of HCVassociated liver disease in a cohort of haemophilic patients. Br J Haematol 1994;87:555-61.

134. Greub G, Ledergerber B, Battegay M, et al. Clinical progression, survival and immune recovery during antiretroviral therapy in patients with HIV-1 and hepatitis C virus co infection: The Swiss HIV Cohort Study. Lancet 2000;356:1800-5.

135. Sulkowski MS, Moore RD, Mehta SH, Chaisson RE, Thomas DL. Hepatitis C and progression of HIV disease. J Am Med Assoc 2002;288:199-206.

136. Klein MB, LaLonde RG, Suissa S. Hepatitis C (HCV) co-infection is preventing the realization of substantial health benefits associated with HAART. Abstract 216. In: 11th Annual Canadian Conference on HIV/AIDS Research 2002, Winnipeg, Manitoba.

137. Chung RT, Evans SR, Yang Y, et al. Immune recovery is associated with persistent rise in hepatitis $\mathrm{C}$ virus RNA, infrequent liver test flares, and is not impaired by hepatitis $\mathrm{C}$ virus in co-infected subjects. AIDS 2002;16:1915-23.

138. Torre D, Tambini R, Cadario F, et al. Evolution of co infection with human immunodeficiency virus and hepatitis $\mathrm{C}$ virus in patients treated with highly active antiretroviral therapy. Clin Infect Dis 2001;33:1579-85.

139. Aceti A, Pasquazzi C, Zechini B. Alanine aminotransferase decrease in HIV-hepatitis $\mathrm{C}$ virus co-infected patients responding to antiretroviral therapy. AIDS 2003;17:2141-2.

140. Perronne C, Carrat F, Bani-Sadr F, et al. Final results of ANRS HCO2-RIBAVIC: A randomized controlled trial of pegylatedinterferon-a-2b plus ribavirin vs. interferon-a- $2 b$ plus ribavirin for the initial treatment of chronic hepatitis C in HIV co-infected patients. Abstract 117LB. In: 11th Conference on Retroviruses and Opportunistic Infections, San Francisco, California, February 2004.

141. Moreno L. Pegylated interferon-alpha $2 b$ plus ribavirin for the treatment of chronic hepatitis $\mathrm{C}$ in HIV-infected patients. AIDS 2004;18:67-73.

142. Chung R, Andersen J, Volberding P, et al. A randomized, controlled trial of PEG-interferon-alpha-2a plus ribavirin vs. interferon-a-2a plus ribavirin for chronic hepatitis $\mathrm{C}$ virus infection in HIV-co-infected persons: Follow-up results of ACTG A5071. Abstract 110. In: 11th Conference on Retroviruses and Opportunistic Infections, San Francisco, California, February 2004.

143. Torriani FJ, Rockstroh J, Rodriguez-Torres M, et al. Final results of APRICOT: A randomized, partially blinded, international trial evaluating peginterferon-a-2a + ribavirin vs. interferon-a- $2 \mathrm{a}+$ ribavirin in the treatment of $\mathrm{HCV}$ in $\mathrm{HIV} / \mathrm{HCV}$ co-infection. Abstract 112. In: 11th Conference on Retroviruses and Opportunistic Infections, San Francisco, California, February 2004.
144. Hammoud G, Li J, Vega K, et al. Poor tolerability to high Dose Peg Interferon and Ribavirin in HIV/HCV co-infected patients; initial results from a randomized multicentre trial. Hepatology 2003;38(Suppl 1):327A.

145. Lafeuillade A, Hittinger G, Chadapaud S. Increased mitochondrial toxicity with ribavirin in $\mathrm{HIV} / \mathrm{HCV}$ co infection. Lancet 2001;357:280-1.

146. Salmon-Ceron D, Chauvelot-Moachon L, Abad S, et al. Mitochondrial toxic effects and ribavirin. Lancet 2001;357:1803-4.

147. Salmon-Ceron D, Chauvelot-Moachon L, Abad S, Silbermann B, Sogni P. Mitochondrial toxic effects and ribavirin. Lancet 2001;357:1803-4.

148. Sim SM, Hoggard PG, Sales SD, et al. Effect of ribavirin on zidovudine efficacy and toxicity in vitro: A concentration-dependent interaction. AIDS Res Hum Retroviruses 1998;14:1661-7.

149. Gisolf EH, Dreezen C, Danner SA, et al. Risk factors for hepatotoxicity in HIV-1-infected patients receiving ritonavir and saquinavir with or without stavudine. Prometheus Study Group. Clin Infect Dis 2000;31:1234-9.

150. Van Leth F, Hassink EA, Phanuphak P, et al. Results of the 2NN Study: A randomized comparative trial of first-line antiretroviral therapy with regimens containing either nevirapine alone, efavirenz alone or both drugs combined together with stavudine and lamivudine. Abstract 176. In: 10th Conference on Retroviruses and Opportunistic Infections, Boston, Massachussetts, February 2003

151. Fortgang IS, Belitsos PC, Chaisson RE, et al. Hepatomegaly and steatosis in HIV-infected patients receiving nucleoside analog antiretroviral therapy. Am J Gastroenterol 1995;90:1433-6.

152. Brinkman K, ter Hofstede HJ, Burger DM, et al. Adverse effects of reverse transcriptase inhibitors: Mitochondrial toxicity as common pathway. AIDS 1998;12:1735-44.

153. Aceti A, Pasquazzi C, Zechini B, De Bac C. Hepatotoxicity development during antiretroviral therapy containing protease inhibitors in patients with HIV: The role of hepatitis B and C virus infection. J Acquir Immune Defic Syndr 2002;29:41-8.

154. Sulkowski MS, Thomas DL, Mehta SH, Chaisson RE, Moore RD. Hepatotoxicity associated with nevirapine or efavirenz-containing antiretroviral therapy: Role of hepatitis C and B infections. Hepatology 2002;35:182-9.

155. Sulkowski MS, Thomas DL, Chaisson RE, Moore RD. Hepatotoxicity associated with antiretroviral therapy in adults infected with human immunodeficiency virus and the role of hepatitis $\mathrm{C}$ or $\mathrm{B}$ virus infection. JAMA 2000;283:74-80.

156. Bourezane Y, Salard D, Hoen B, Vandel S, Drobacheff C, Laurent R. DRESS (drug rash with eosinophilia and systemic symptoms) syndrome associated with nevirapine therapy. Clin Infect Dis 1998;27:1321-2.

157. Martinez E, Blanco JL, Arnaiz JA, et al. Hepatotoxicity in HIV-1infected patients receiving nevirapine-containing antiretroviral therapy. AIDS 2001;15:1261-8.

158. Guidelines for the use of antiretroviral agents in HIV-1 infected adults and adolescents. Developed by the Panel on Clinical Practices for Treatment of HIV Infection convened by the Department of Health and Human Services. November 2003.

159. Dieterich DT. Treatment of hepatitis $C$ and anemia in human immunodeficiency virus-infected patients. J Infect Dis 2002;185(Suppl 2):S128-37.

This article also appears in Can J Infect Dis Med Microbiol 2004;15:313-326 


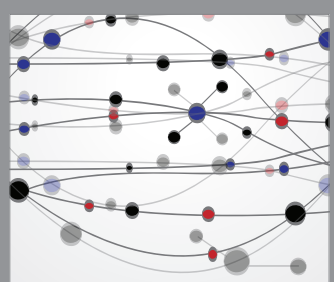

The Scientific World Journal
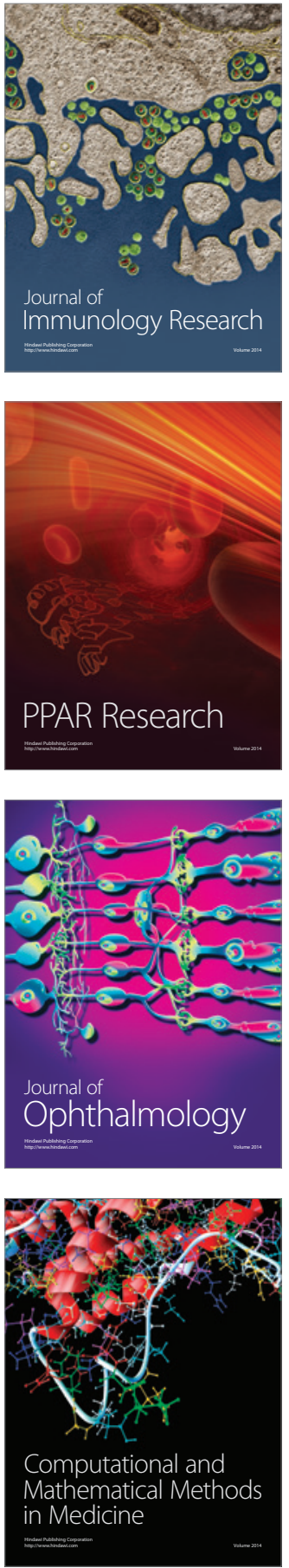

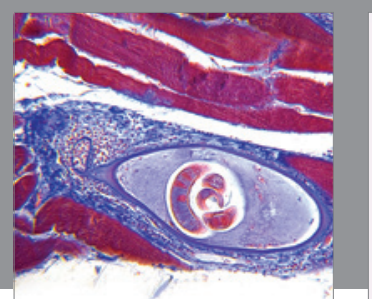

Gastroenterology Research and Practice

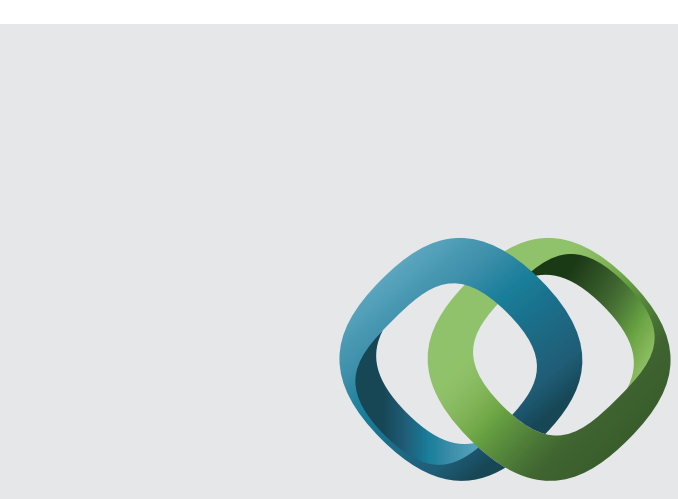

\section{Hindawi}

Submit your manuscripts at

http://www.hindawi.com
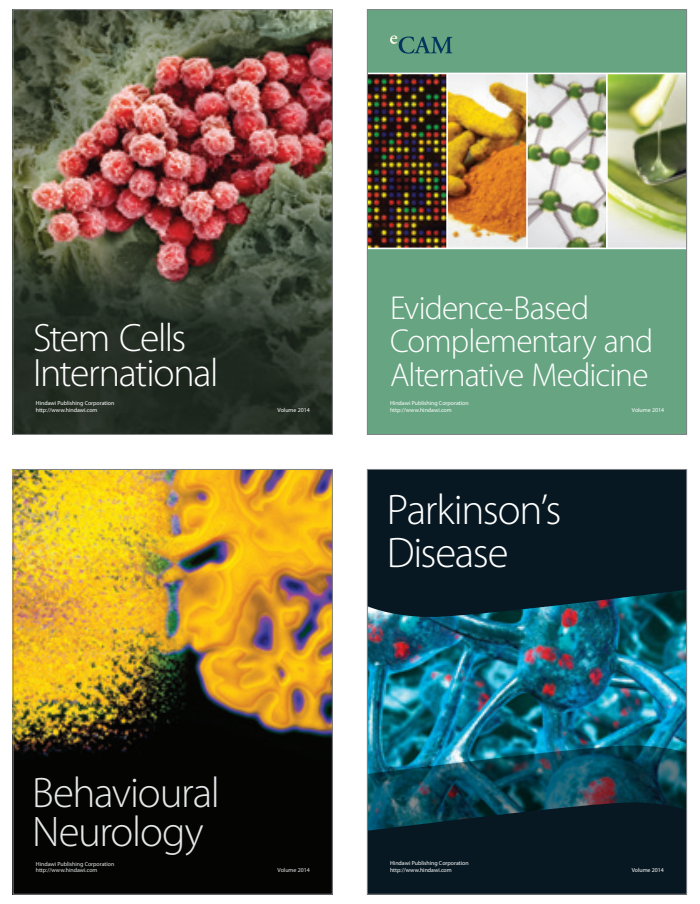
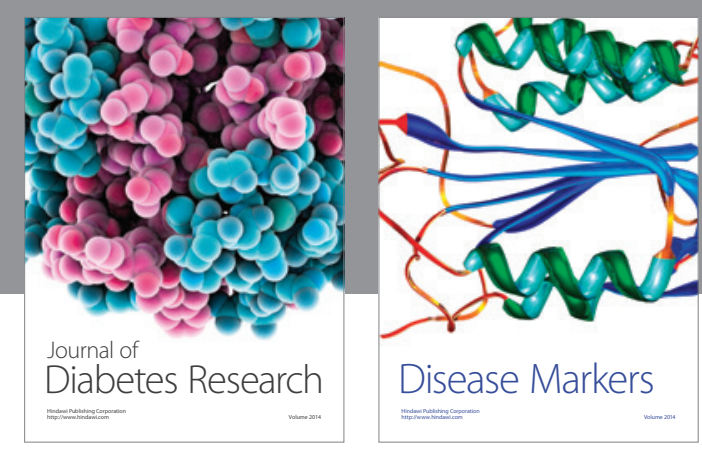

Disease Markers
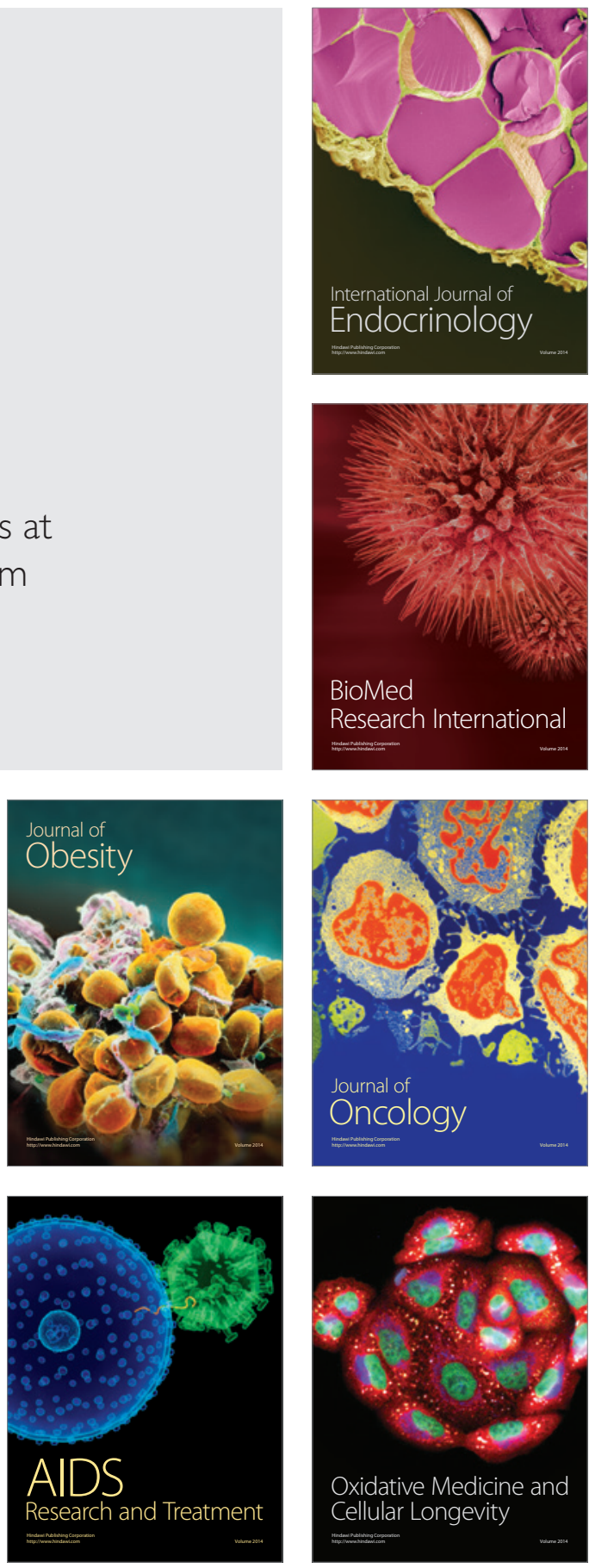